\title{
ТЕРМИЧЕСКОЕ РАЗЛОЖЕНИЕ КАТИОННЫХ, АНИОННЫХ И ДВОЙНЫХ КОМПЛЕКСНЫХ СОЕДИНЕНИЙ Зd-МЕТАЛЛОВ
}

\author{
С. И. Печенюк, Д. П. Домонов, А.Н. Гостева
}

\begin{abstract}
СОФИЯ ИВАНОВНА ПЕЧЕНЮК - доктор химических наук, главный научный сотрудник Института химии и технологии редких элементов и минерального сырья им. И.В. Тананаева КНЦ РАН (ИХТРЭМС КНЦ РАН). Область научных интересов: координационная химия, поверхностные явления, гетерогенный катализ. E-mail: pechenyuk@chemy.kolasc.net.ru.
\end{abstract}

ДЕНИС ПЕТРОВИЧ ДОМОНОВ - кандидат химических наук, стариий научный сотрудник ИХТРЭМС КНЦ РАН. Область научных интересов: координационная химия, термический анализ, гетерогенный катализ.E-mail: domonov@chemy.kolasc.net.ru.

АЛЕВТИАНА НИКОЛАЕВНА ГОСТЕВА - кандидат химических наук, старший научный сотрудник ИХТРЭМС КНЦ РАН. Область научных интересов: координационная химия, термический анализ, гетерогенный катализ. E-mail: fiona_tolk@bk.ru.

Российская Федерация, 184209 Anатиты, Академгородок, 26а. Институт химии и технологии редких элементов и минерального сырья им. И.В. Тананаева Кольского научного иентра РАН.

Обзор посвящен рассмотрению термического поведения катионных, анионных и двойных комплексных соединений $3 d$ металлов (Fe, Co, $\mathrm{Ni}, \mathrm{Cu}, \mathrm{Mn}, \mathrm{Cr}$ ) в сравнении с комплексами благородных металлов, с координированными аммиаком, органическими аминами, мочевиной, циианидом, тиоцианатом, оксалатом и нитритом. Показано, что в проиессе термолиза, проводимого в неравновесных условиях, двойнье комплексы выдерживают нагревание до 200-250 ${ }^{\circ} \mathrm{C}$ вне зависимости от их термодинамической устойчивости.

Ключевые слова: 3d-металлы, комплексные соединения, центральный ион, лиганды, термическое разложение, продукты термолиза.

\section{THERMAL DECOMPOSITION OF CATIONIC, ANIONIC AND DOUBLE COMPLEX COMPOUNDS OF 3d METALS}

\author{
S. I. Pechenyuk, D. P. Domonov, A. N. Gosteva
}

26 a, «Academic town», Apatity, Murmansk region, 184209, Russia. Tananaev Institute of Chemistry - Subdivision of the Federal Research Centre "Kola Science Centre of the Russian Academy of Sciences» .

The review deals with the thermal behavior of cationic, anionic and double complex compounds of $3 d$ metals ( $\mathrm{Fe}, \mathrm{Co}, \mathrm{Ni}, \mathrm{Cu}, \mathrm{Mn}, \mathrm{Cr}$ ) and partly silver, gold and platinum metals, with coordinated ammonia, organic amines, urea, pseudohalides, oxalate and nitrite. It is shown that in the thermolysis process carried out under nonequilibrium conditions, the double complexes can withstand heating to $200-250^{\circ} \mathrm{C}$, regardless of their thermodynamic stability.

Key words: 3d-metals, complex compounds, central ion, ligands, thermal decomposition, thermolysis products. 


\section{Введение}

Термическое разложение двойных комплексных соединений (ДКС) признано ныне перспективным методом получения композиционных материалов, многие из которых не могут быть получены иными методами, например, ряд метастабильных биметаллических систем или металлуглеродных композиций [1-4]. Термолиз, в общем, представляет собой твердофазный сложный процесс, включающий окислительно-восстановительные реакции и реакции замещения в объеме твердой фазы и на границах раздела твердых фаз, образование новых твердых фаз и границ раздела с формированием пористой структуры, кристаллизацию и высвобождение (элиминирование) газов из твердой фазы. Если мы хотим направлять ход процесса на получение определенных продуктов, то эта сложность процесса заставляет принимать во внимание многие факторы.

Цель настоящего обзора - систематизировать и обобщить имеющиеся в литературе данные о термолизе комплексов 3d-металлов и проследить общие закономерности термолиза их ДКС путем сравнения термолизом ДКС благородных металлов.

Основными факторами, влияющими на ход термолиза, являются, во-первых, природа центральных ионов (ц.и.) и лигандов, определяющие термодинамическую устойчивость комплекса. Как количественные характеристики здесь могут быть приняты энтальпии образования соединений и термодинамические константы устойчивости комплексов. Во-вторых, поскольку реакции замещения участвуют в общем процессе, необходимо учитывать кинетические характеристики (скорости замещения лигандов в исходных и про- межуточных продуктах [4]). В-третьих, поскольку образование новых твердых фаз и элиминирование газообразных продуктов термолиза сопряжены с перемещением (диффузией) атомов внутри твердой фазы и через границы раздела, важное значение имеет кристаллическая структура исходного и промежуточных продуктов.

Известно, что структуры многих комплексных соединений, особенно двойных, т.е. состоящих из комплексных катионов и анионов, являются островными, а именно, комплексные катионы и анионы в определенном порядке занимают чередующиеся позиции в кристаллической решетке, не будучи связаны между собой ничем, кроме электростатических сил и слабых Ван-дер-Ваальсовых взаимодействий. В этом случае мы имеем дело с практически неискаженными координационными полиэдрами [5]. При соотношениях ц.и., равных 4:3 или 3:4 и выше в островной структуре образуются туннели, заполненные молекулами кристаллизационной воды [6] (рис. 1). Структуры, обозначаемые $1 \mathrm{D}$, состоят из цепей, образованных координационными полиэдрами, соединенными общими вершинами или связями металл-металл, как в $\left[\mathrm{PtCI}_{4}\right]_{\mathrm{n}}[4,7] .2 \mathrm{D}$-структуры состоят из полиэдров, соединенных общими ребрами или мостиковыми лигандами [8]. Наконец, 3D-структуры образуют трехмерные каркасы за счет использования мостиковых атомов (групп) или лигандов и имеют общие грани полиэдров [9] (рис. 2). Во всех этих случаях условия диффузии и роста новых фаз совершенно различны.

В пользу применения термолиза ДКС для получения биметаллических материалов часто приводят соображение, что строго определенные стехиометрические соотношения между составляю-

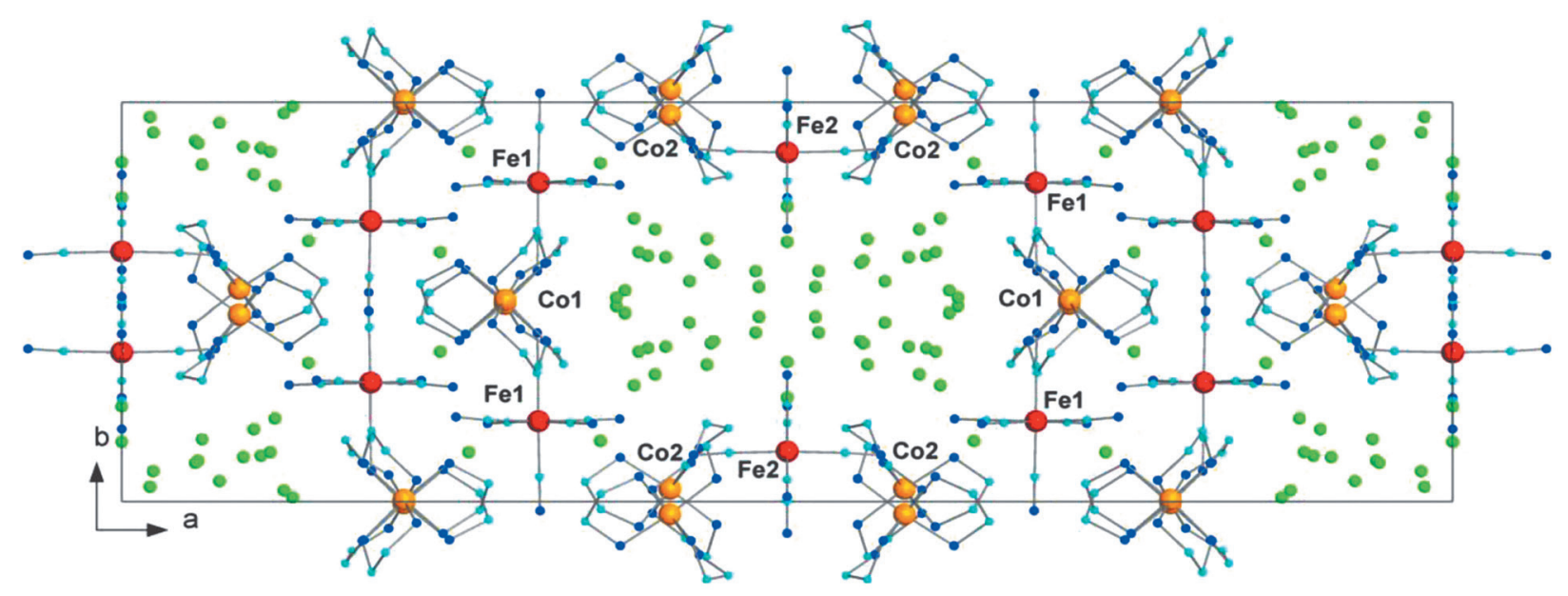

Рис. 1. Вид на основной элемент структуры $\left[\mathrm{Co}(\mathrm{en})_{3}\right]_{4}\left[\mathrm{Fe}(\mathrm{CN})_{6}\right]_{3} \cdot 21,6 \mathrm{H}_{2} \mathrm{O}$ в направлении с [6] Атомы водорода опущены для четкости рисунка 
щими комплекс атомами обеспечивают высокую гомогенность получаемого материала. Между тем, если это и верно в значительной степени для подгруппы платиновых металлов, которые все имеют высокое сродство друг к другу, обеспечивающее образование их твердых растворов [5, 10-12], для 3d-металлов, это сродство значительно меньше, и гомогенные материалы получаются только если металлы образуют металлические твердые растворы или шпинели [13-15].

Вопрос о возможности использования в целях прогнозирования термического поведения комплексов величин констант устойчивости или констант скоростей замещения лигандов уже давно поставлен исследователями, но из дальнейшего будет видно, что нужно делать это с большой осторожностью. Подавляющее большинство этих характеристик определено путем изучения равновесий образования комплексов в водных растворах, то есть так называемыми «мокрыми» методами, следовательно, так или иначе отражают участие воды в процессе. В следующем разделе этот вопрос будет рассмотрен подробно.
Как будет видно из последующего, природа атмосферы, в которой проводится термолиз, имеет, наряду с природой комплекса, решающее значение для результатов термолиза. Казалось бы, это очевидно, но как будет видно из дальнейшего, пока комплекс не потерял свой индивидуальности за счет нагрева, природа атмосферы как раз не имеет значения, но начинает сказываться сразу после начала разложения, то, поскольку нас интересуют конечные продукты, мы должны обратить внимание на это обстоятельство. Окислительная и восстановительная атмосферы видоизменяют природу продуктов термолиза за счет взаимодействия с ними, инертная атмосфера и вакуум не изменяют качественно состав продуктов термолиза по сравнению с исходным веществом. То есть, как правило, в них обнаруживаются все те элементы, что и в исходном веществе, хотя, конечно, в иных количественных соотношениях за счет перехода части их в газовую фазу, но не появляется никаких дополнительных, кроме элементов газовой среды. Это очень важно учитывать при рассмотрении процесса термолиза, поэтому
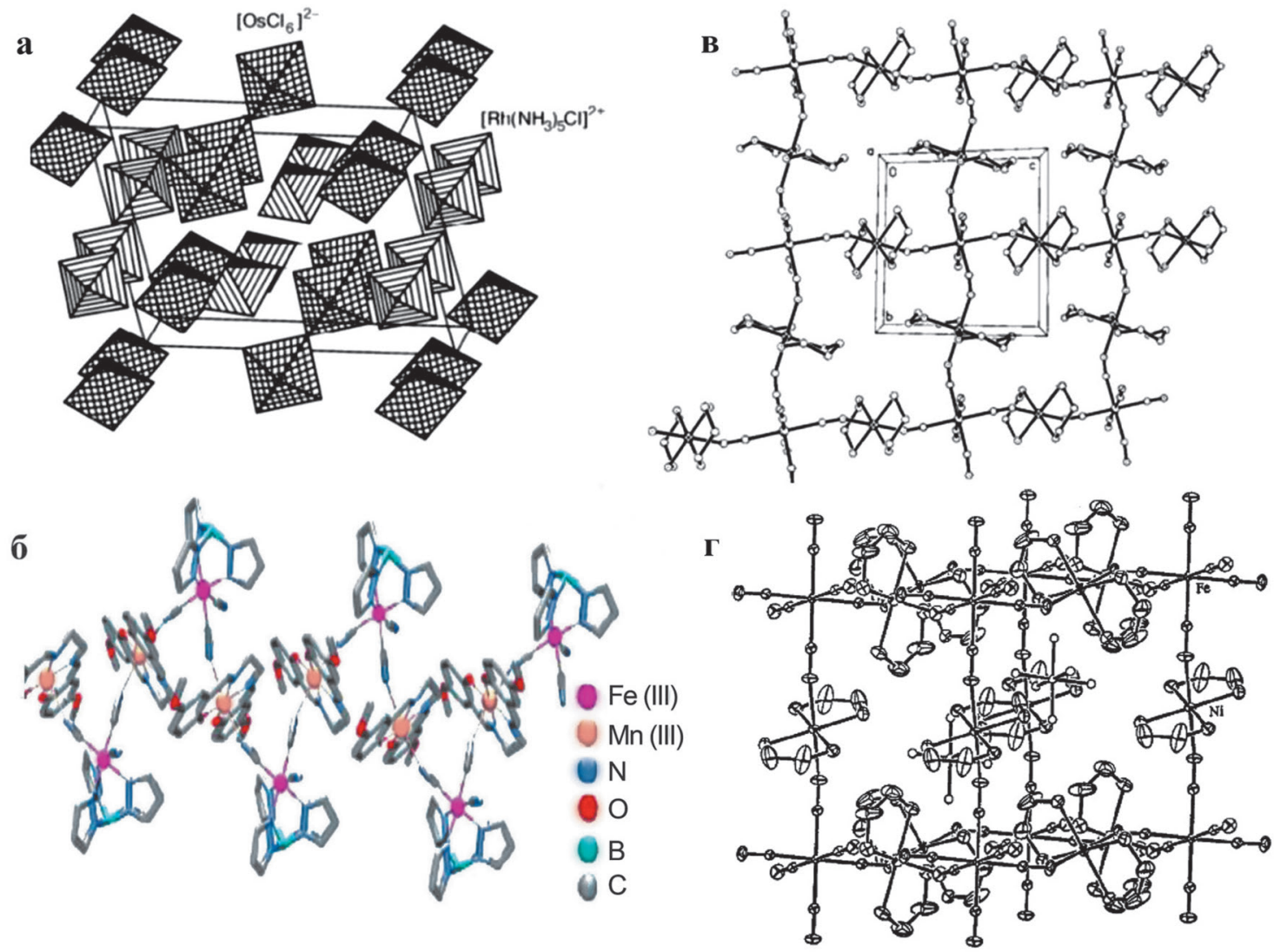

Рис. 2. Виды кристаллической структуры:

a-островная структура $\left[\mathrm{Rh}\left(\mathrm{NH}_{3}\right)_{5} \mathrm{Cl}\right]\left[\mathrm{OsCl}_{6}\right][6]$;

б - $1 \mathrm{D}$ структура $\left[\left(\mathrm{L}_{1}\right) \mathrm{Fe}(\mathrm{CN})_{3} \mathrm{Mn}\left(\mathrm{N}, \mathrm{N}^{\prime}-\mathrm{L}_{2}\right) \cdot 2 \mathrm{CH}_{3} \mathrm{OH}\right]_{n} L_{1}=($ гидротрис (пиразолил)борат),

$L_{2}=$ этиленбис(5-метоксисалицилиденеиминат) [7]; в - 2D cmpуктура $\left[\mathrm{Ni}(\mathrm{tn})_{2}\right]_{2}\left[\mathrm{Cr}(\mathrm{CN})_{5}(\mathrm{NO})\right] \mathrm{OH} \cdot \mathrm{H}_{2} \mathrm{O}[8]$; г - 3D кубическая ячейка $\mathrm{Fe}_{8} \mathrm{NI}_{12}$ в ДКC [Ni(en) $\left.{ }_{2}\right]_{3}\left[\mathrm{Fe}(\mathrm{CN})_{6}\right]\left(\mathrm{PF}_{6}\right)_{2}[9]$ 
в дальнейшем мы будем указывать, в какой атмосфере проводили термолиз авторы той или иной оригинальной работы.

Предположение, что при термолизе ДКС разложение катионной и анионной частей должно происходить раздельно, представляет собой естественное заблуждение, основанное на значительном различии в ходе термолиза катионных и анионных частей двойных комплексов. Рассмотрение термолиза катионных, анионных и двойных комплексов раздельно позволит нам установить очередность стадий процесса.

\section{1. Термолиз катионных комплексов}

Для катионных комплексов характерно наличие во внутренней сфере нейтральных лигандов (вода, аммиак, амины, мочевина и их производные) и простых кислотных остатков во внешней сфере. Кроме того, в большинстве случаев эти соединения содержат несколько молей кристаллизационной воды на моль комплекса. Из числа нейтральных лигандов наиболее часто употребляются аммиак [16-30] и органические диамины [31-43], образующие наиболее прочные и инертные соединения с переходными металлами $\mathrm{d}^{5}-\mathrm{d}^{10}$. Широкие исследования термической устойчивости комплексов преимущественно гексаминового типа проведены Вендландтом с сотрудниками [16, 17, 20, 29, 40, 43]. Для аммиачных комплексов состава $\left[\mathrm{M}\left(\mathrm{MH}_{3}\right)_{6}\right]^{2+}$, где $\mathrm{M}=\mathrm{Cr}, \mathrm{Co}, \mathrm{Ni}, \mathrm{Mn}$, изучен термолиз их галогенидов, нитратов, перхлоратов и оксалатов в окислительной (воздух), инертной (аргон, гелий) атмосферах и в вакууме [30]. Установлено, что при термолизе в этих средах сначала отщепляется внешнесферная вода и потом ступенчато аммиак, что сопровождается эндотермическими эффектами. Со(III) обязательно восстанавливается за счет лигандов до Сo(II). В работах [21-24, 26, 27], изучен термолиз аммиакатов кобальта, никеля, кадмия, марганца в атмосфере аргона и воздуха [28]. По мере удаления нейтральных лигандов устойчивые внешнесферные анионы, такие как галогениды или оксалат и сульфат, могут частично вступать во внутреннюю сферу $[18,19,27,28]$. Если комплексные соли были галогенидами, в остатке от прокаливания остаются галогениды ц.и. Если это были нитраты [21-25], то в инертной среде тоже образуются нитраты ц.и., которые при нагревании разлагаются со взрывом. Конечными твердыми продуктами термолиза любого комплекса в атмосфере воздуха являются оксиды ц.и., в вакууме - галогениды из галогенидов, всегда оксиды из взрывоопасных нитратов и перхлоратов [26]. Внешнесферные анионы сильно, но по-разному влияют на скорость термического окисления $\left[\mathrm{Co}(\mathrm{en})_{3}\right]^{3+}: \mathrm{Cl}>\mathrm{Br}>\mathrm{I}>$ $>\mathrm{NCS}>\mathrm{NCO}$ [37] и термического восстановления гексаммина кобальта(III) водородом: $\mathrm{OH}<\mathrm{SCN}<$ $<\mathrm{I}<\mathrm{CN}, \mathrm{Br}<\mathrm{Cl}<\mathrm{SO}_{4}<\mathrm{C}_{2} \mathrm{O}_{4}$ [44]. Внешнесферные сульфат-ионы $[40,41]$ за счет окислительно-восстановительных взаимодействий с лигандами образуют серу и сульфиды ц.и. Внешнесферные оксалатионы $[27,28,42]$ в силу своих сильных восстановительных свойств восстанавливают некоторые ц.и., например, кобальт и никель, до металла. Все основные превращения такого рода происходят в области $100-200{ }^{\circ} \mathrm{C}$. Газообразные продукты термолиза аммиачных галогенидов представляют собой аммиак, галогениды аммония, галоиды, в вакууме дополнительно появляются азот, водород, продукты термолиза нитратов - окислы азота, вода, азот, оксалатов, карбонатов $-\mathrm{CO}, \mathrm{CO}_{2}$.

Также велико количество работ, посвященных комплексам, содержащим этилендиамин и мочевину, другие же нейтральные лиганды встречаются эпизодически. При замене аммиака как лиганда на сложные органические лиганды (амины би- и полидентатные, мочевина, пиридин, фенантролин, бипиридил и т.п. [29-63]) все возрастающую роль должна играть собственная термическая устойчивость лиганда и термодинамическая устойчивость комплекса. Например, при термолизе смешанных комплексов, содержащих этилендиамин и фенантролин, типа $\left[\mathrm{Co}(\mathrm{en})_{\mathrm{x}}(\mathrm{phen})_{\mathrm{y}}\right] \mathrm{Cl}_{3}$, фенантролин постепенно вытесняет этилендиамин [31]. При термолизе комплексов, содержащих бидентатные органические лиганды, на первых стадиях процесса отщепляется один лиганд, что приводит к образованию цис-тетраминов, а затем диаминов, что позволяет получать продукты, которые не образуются в растворе [39]. Однако характер процесса мало зависит от атмосферы: даже комплекс $\left[\mathrm{Cu}(\mathrm{tn}) \mathrm{Cl}_{2}\right]$, имеющий всего один аминный цикл и структуру $1 \mathrm{D}$, сходную с веревочной лестницей, при термолизе сначала испытывает деаминацию и лишь потом теряет ионы хлора [38].

Вопрос о соотношении между термодинамической и термической устойчивостью комплексов был поставлен, например, Боуменом [45] в 1966 г. и рассмотрен на примере серии диаминов 1 переходного ряда элементов состава $\left[\mathrm{M}(\mathrm{py})_{2} \mathrm{X}_{2}\right]$, где $\mathrm{M}$ $\mathrm{Cu}, \mathrm{Ni}, \mathrm{Co}, \mathrm{Mn}, \mathrm{Zn}, \mathrm{X}-\mathrm{Cl}^{-}, \mathrm{NO}_{3}^{-}$, $\mathrm{CNS}^{-}$; $\mathrm{py}$ - пиридин, и ряда комплексов меди с замещенными пиридинами. В работе [45] довольно категорично утверждается, что термическая устойчивость коррелирует с термодинамической константой устойчивости, определенной в растворе, и с энергией связи, определяющей дальнюю область поглощения в ИК-спектре. То есть термическая устойчивость комплекса возрастает с увеличением его ста- 
Константы устойчивости катионных аминных комплексов $[46,47]$ для области температур $20-30$ 'C

\begin{tabular}{ccccccc}
\hline Центральный ион, & $\mathbf{C o}(\mathbf{I I})$ & $\mathbf{C o}(\mathbf{I I I})$ & $\mathbf{N i}(\mathbf{I I})$ & $\mathbf{C d}(\mathbf{I I})$ & $\mathbf{M n}(\mathbf{I I})$ & $\mathbf{C u}(\mathbf{I I})$ \\
\hline $\mathrm{K}_{\text {уст }}\left[\mathrm{M}\left(\mathrm{NH}_{3}\right)_{6}\right]^{2+}$, & $1,3 \cdot 10^{6}$ & $1,6 \cdot 10^{35}$ & $5 \cdot 10^{8}$ & $1,4 \cdot 10^{5}$ & $10^{9 * *}$ & $5 \cdot 10^{12 * * *}$ \\
$\mathrm{t}^{\circ} \mathrm{C}$, & 30 & 30 & 30 & 30 & & 30 \\
$\mu^{*}$ & $0,5-5,0$ & 2,0 & $0,5-5,0$ & $0,5-5,0$ & & $0,5-5,0$ \\
\hline $\mathrm{K}_{\text {уст }}\left[\mathrm{M}(\mathrm{en})_{3}\right]^{z+}$, & $1 \cdot 10^{14}$ & $5 \cdot 10^{48}$ & $4 \cdot 10^{18}$ & $2 \cdot 10^{12}$ & $5 \cdot 10^{5}$ & $1,5 \cdot 10^{20 * * * *}$ \\
$\mathrm{t}^{\circ} \mathrm{C}$, & 25 & 30 & 25 & 25 & 30 & 25 \\
$\mu^{*}$ & 1,0 & 1,0 & 0,5 & 1,0 & 1,0 & 0,5 \\
\hline \multirow{*}{*}{} & & & & &
\end{tabular}

* $\mu$-ионная сила.

** ориентировочно.

$* * *\left[\mathrm{Cu}\left(\mathrm{NH}_{3}\right)_{4}\right]^{2+}$.

$* * * *\left[\mathrm{Cu}(\mathrm{en})_{2}\right]^{2+}$.

бильности в растворе. Наоборот, увеличение числа заместителей в замещенном пиридине как лиганде вызывает обратное влияние на термическую устойчивость. Наличие у лигандов сильно разветвленного скелета приводит к уменьшению термической устойчивости комплекса [45]. Однако количественно наблюдаемые эффекты малы: соответственные точки на термограммах здесь отличались на 20-50 град.

Рассмотрим другой пример: сравнительное поведение комплексных гексаминов с легко летучими лигандами - аммиаком и этилендиамином. В таблице 1 приведены величины констант образования (устойчивости) этих комплексов для ряда 3d-элементов. На рис. 3 и 4 представлены результаты термического анализа (кривые ТГ) соответствующих катионных комплексов 3d-металлов, собранные из различных работ. Ход термического разложения очень сильно зависит от природы газовой среды, в которой проходит термолиз. На рис. 3 и 4 приведены данные для инертных сред и окислительной, т.е. воздушной, соответственно.

Рассмотрение и сопоставление этих данных позволяет заключить, что, в общем, аммиачные катионные комплексы заканчивают разлагаться при несколько более низких температурах, чем этилендиаминовые. Однако температура, при которой аммиак или этилендиамин полностью удаляется из остатка от прокаливания, сильно зависит, от природы внешнесферного аниона, что видно из сравнения хлоридов и нитратов [19-28]. При этом надо отметить, что в работах [20, 22-24] удаление аммиака наблюдается уже значительно ниже $100{ }^{\circ} \mathrm{C}$. Кроме того, разложение аммиачных катионных комплексов происходит ступенчато: так, согласно [22], 4 моля аммиака отщепляются от $\left[\mathrm{Co}\left(\mathrm{NH}_{3}\right)_{6}\right]\left(\mathrm{NO}_{3}\right)_{3}$ до $150{ }^{\circ} \mathrm{C}$, отщепление же остальных происходит одновременно с разложением нитрат-ионов. Аналогично, разложение $\left[\mathrm{Cu}\left(\mathrm{NH}_{3}\right)_{6}\right] \mathrm{Cl}_{2}$ до $\left[\mathrm{Cu}\left(\mathrm{NH}_{3}\right)_{2}\right] \mathrm{Cl}_{2}$ [52] заканчивается при $175{ }^{\circ} \mathrm{C}$, после чего начина- ется восстановление $\mathrm{Cu}(\mathrm{II})$ до $\mathrm{Cu}(\mathrm{I})$ за счет окисления оставшегося аммиака. Из $\left[\mathrm{Co}(\mathrm{en})_{3}\right] \mathrm{Cl}_{3}$ en начинает выделяться при $245^{\circ} \mathrm{C}$ и образуется интермедиат $\left[\mathrm{Co}(\mathrm{en})_{2} \mathrm{Cl}_{2}\right] \mathrm{Cl}[32]$.

Вообще сравнение результатов термического анализа, как катионных комплексов, так и ДКС $[13-15,17,20,24,35,38,49-51]$, включая приведенные здесь результаты, показывает очень большое сходство соответствующих кривых ТГ (рис. 3, 4). Начальный период термолиза (нагрев до 200-250 ${ }^{\circ} \mathrm{C}$, потеря массы $\sim 30$ \%) характеризуется, прежде всего, отщеплением части нейтральных лигандов комплексного катиона, после чего комплексы теряют первоначальную структуру, и говорить об их устойчивости уже не имеет смысла. Широкое расхождение кривых ТГ после этой температуры (см. рис. 3,4$)$ относится уже не к самим комплексам, а к продуктам их разложения. На рис. 3 видно, что выделение нейтральных лигандов, особенно аммиака, происходит для всех катионных комплексов в очень узкой температурной области, совершенно независимо от величины константы устойчивости. По величинам остатков от прокаливания видно, что ветви кривых соответствуют продуктам их разложения. При этом для очень устойчивых и очень неустойчивых комплексов (см. табл. 1, рис. 3) начало разложения имеет место практически в одном и том же температурном интервале - от 0 до $300^{\circ} \mathrm{C}$. Хотя комплексы Co(III) очень устойчивы, но в области температур $>200{ }^{\circ} \mathrm{C}$ мы, по-видимому, имеем дело уже с комплексами $\mathrm{Co}(\mathrm{II})$, а не $\mathrm{Co}(\mathrm{III})$, из-за восстановления последнего лигандами.

Согласно классическим представлениям [4], чем ниже энергия образования комплекса, тем ниже энергия, необходимая для его разрушения и, следовательно, ниже его термическая устойчивость. Видно, что для аммиачных комплексов термическая устойчивость приблизительно коррелирует с константой устойчивости, но зависи- 
ТГ, мacc. $\%$

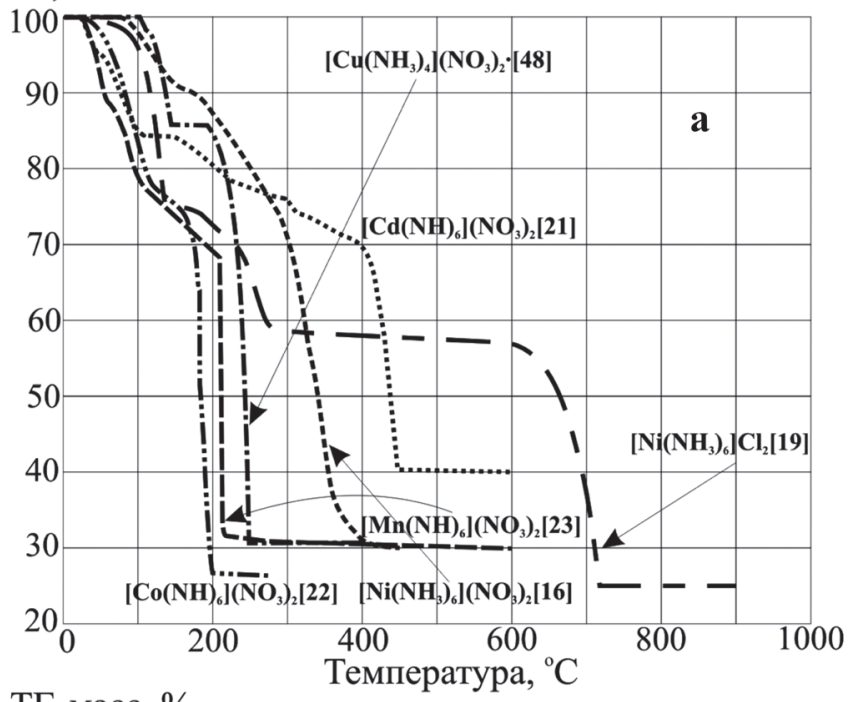

ТГ, мacc. \%

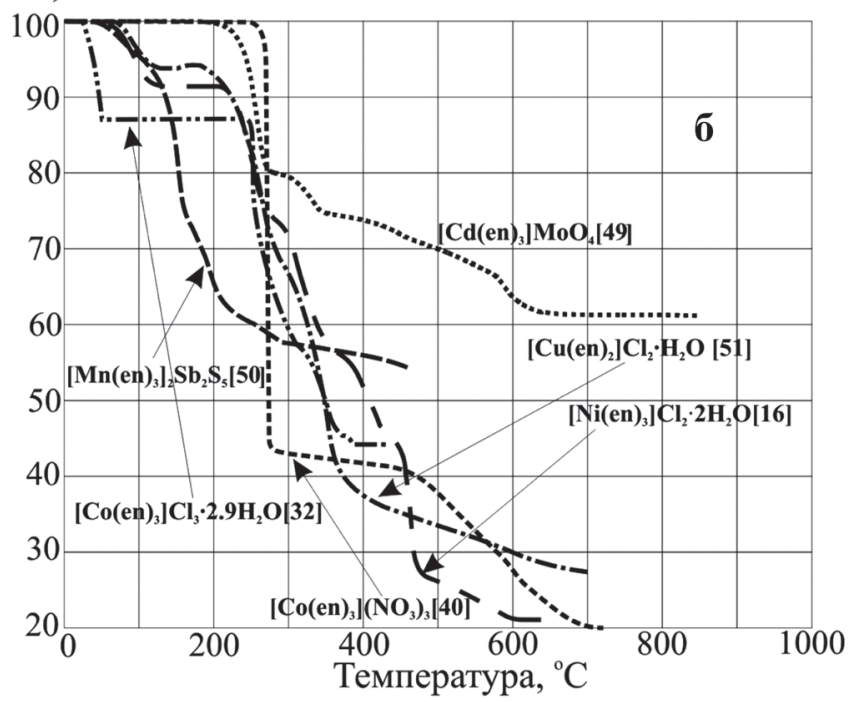

Рис. 3. Кривые термического анализа (ТГ) катионных комплексов в инертной атмосфере:

$\mathbf{a}$-аммиачные; б-этилендиаминовые

мость слабая. Если попытаться сопоставить приведенные в табл. 1 и на рис. 3, 4 данные с величинами энтальпий образования катионных комплексов (от 100 до 25 кДж/моль) с этилендиамином [53]: $\Delta \mathrm{H}_{0 \text { бр }}\left[\mathrm{Ni}(\mathrm{en})_{3}\right]^{2+}>\left[\mathrm{Cu}(\mathrm{en})_{2}\right]^{2+}>\left[\mathrm{Cd}(\mathrm{en})_{3}\right]^{2+}>$ $\left[\mathrm{Mn}(\mathrm{en})_{3}\right]^{2+}$, мы не увидим корреляции. Ответить на поставленный вопрос можно, вероятно, так: если это верно, то только в пределах узкой группы комплексов аналогичного строения.

По мере усложнения состава нейтральных лигандов в число происходящих при термолизе превращений включаются превращения лиганда. К сожалению, вопрос об этих превращениях недостаточно хорошо изучен. В отношении координированных аминов удалось установить, что одним из главных продуктов их разрушения является аммиак [20], но вопрос о судьбе углеродного скеле-
ТГ, мacc. \%

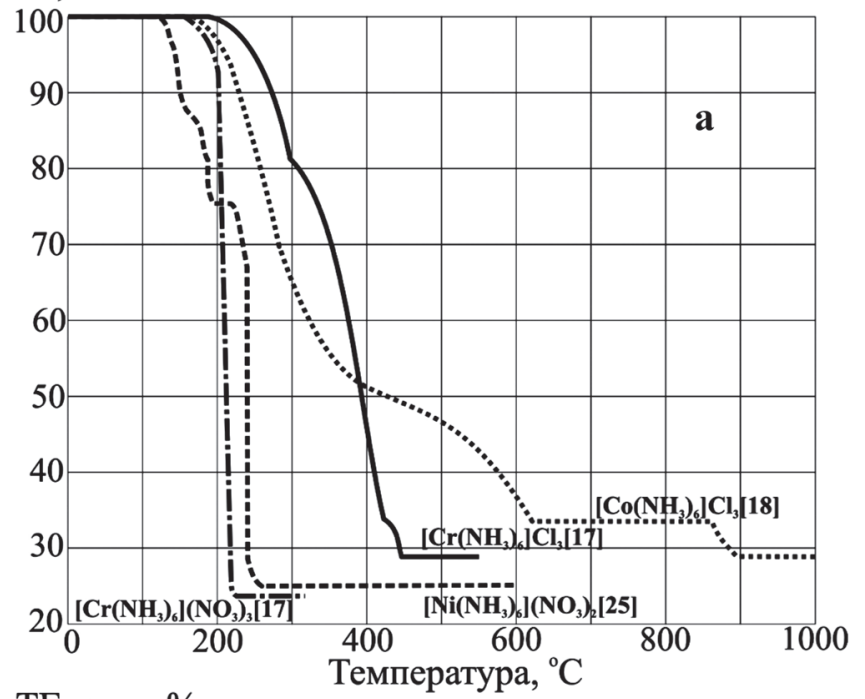

\section{ТГ, мacc. \%}

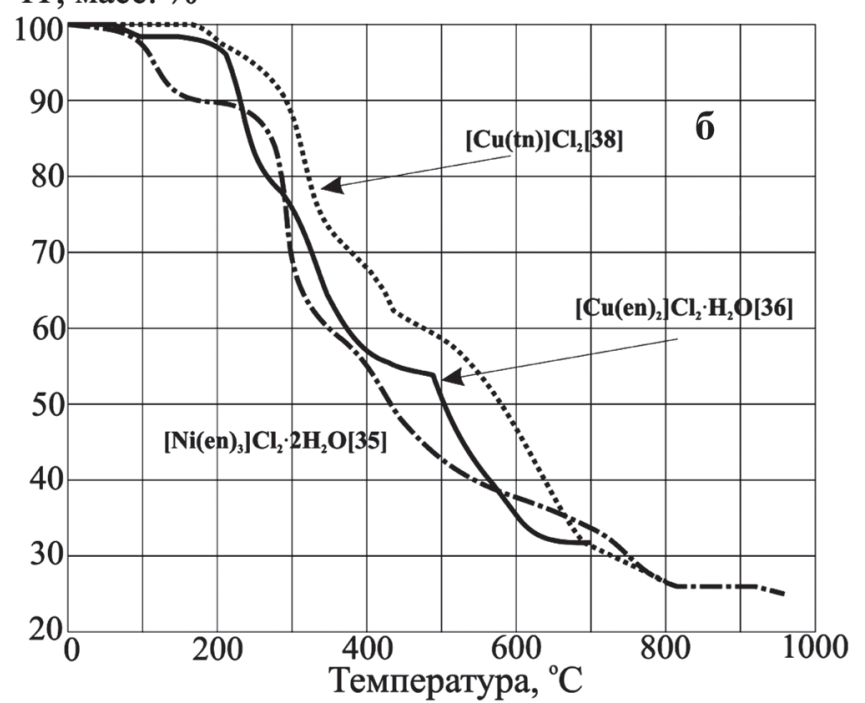

Рис. 4. Кривые термического анализа (ТГ) катионных комплексов на воздухе:

a-аммиачные; $\mathbf{6}$ - этилендиаминовые

та амина остается открытым. Есть некоторые указания [54] на образование непредельных моноаминов: в МС-спектрограммах встречаются производные с м.ч., соответствующими этану, этилену (для этилендиамина) или пропану, пропилену (для триметилендиамина) [55]. Продукты радиационного разложения этилендиамина представляют собой аммиак и ацетилен [54].

Из числа нейтральных лигандов наиболее подробно изучены превращения координированной мочевины [56-63]. Найдено [56], что до $133{ }^{\circ} \mathrm{C}$ никаких превращений свободной мочевины не происходит; до $152{ }^{\circ} \mathrm{C}$ имеет место частичная возгонка мочевины, а от $160{ }^{\circ} \mathrm{C}$ начинается разложение мочевины с образованием аммиака и изоциановой кислоты HNCO и цианата аммония, причем изоциановая кислота в этом температурном интерва- 
ле реагирует с оставшейся мочевиной с образованием биурета. В качестве летучих продуктов разложения собственно мочевины найдены аммиак, изоциановая кислота, окислы азота и углерода. В твердой фазе обнаруживаются такие продукты разложения, как аммелин, аммелид и меламин. Для всех комплексов имеется более или менее заметная стадия, соответствующая удалению неразложившейся мочевины. Комплексы $\left[\mathrm{Cr}(\mathrm{ur})_{6}\right] \mathrm{X}_{3}$ $\left(\mathrm{X}=\mathrm{NO}_{3}, \mathrm{Cl}\right)$ [57] разлагаются до 450 и $525^{\circ} \mathrm{C}$, соответственно. Изоструктурные триклинные [Cr(ur) $\left.{ }_{6}\right]$ $\mathrm{X}_{3}\left(\mathrm{X}=\mathrm{ClO}_{4}, \mathrm{Cl}, \mathrm{BF}_{4}\right)$ [58] устойчивы в атмосфере аргона до 500,440 и $470{ }^{\circ} \mathrm{C}$. Перхлорат разлагается со взрывом, хлорид в две стадии, фтороборат в четыре. Комплекс $\left[\mathrm{Cu}(\mathrm{ur})_{4}\right] \mathrm{Cl}_{2}[59]$ устойчив к нагреванию до $155{ }^{\circ} \mathrm{C}$, при дальнейшем нагревании на воздухе разлагается в 4 стадии с образованием ряда интермедиатов. При $380{ }^{\circ} \mathrm{C}$ вся мочевина уже удалена из внутренней сферы. Мочевина соединяется с медью через кислород. С катионом магния мочевина образует ряд комплексов с 2, 4 и 6 координированными молекулами, термостойкость которых(комплексов) увеличивается с увеличением к.ч. [60]. В качестве продуктов разложения мочевины здесь также найдены аммиак, изоциановая кислота, циануровая кислота и меламин. В настоящее время комплексы с мочевиной рассматриваются в числе важнейших прекурсоров для синтеза смешанных оксидов и изучения их термических свойств [60]. Примеры таких синтезов представляют работы [61-63], где высокодисперсные оксиды смешанной валентности получают термолизом комплексов $\left[\mathrm{Co}(\mathrm{ur})_{6}\right]\left(\mathrm{NO}_{3}\right)_{2}$ и $\left[\mathrm{Mn}(\mathrm{ur})_{6}\right]\left(\mathrm{NO}_{3}\right)_{2} \cdot 2 \mathrm{H}_{2} \mathrm{O}$ в токе воздуха или инертного газа.

Описан термолиз комплексов $\mathrm{Ni}(\mathrm{II})$ с 1,3-диаминопропаном (tn), аналогичных комплексам с этилендиамином [39]. Интересно, что c tn $\mathrm{Ni}(\mathrm{II})$ может проявлять к.ч. как 6 , так и 4. Если $\left[\mathrm{Ni}(e n)_{3}\right]$ $\mathrm{Cl}_{2} \cdot 2 \mathrm{H}_{2} \mathrm{O}$ начинает обезвоживаться при 140 , а разлагаться при $190{ }^{\circ} \mathrm{C}$, то $\left[\mathrm{Ni}(\text { tn })_{3}\right] \mathrm{Cl}_{2} \cdot 2 \mathrm{H}_{2} \mathrm{O}-$ при 105 и $135{ }^{\circ} \mathrm{C}$, соответственно, через ряд аналогичных стадий образования бис-, моно- и гемидиаминов. Замена внешнесферного хлорид-иона на бромид еще снижает термическую устойчивость $\left[\mathrm{Ni}(\mathrm{tn})_{3}\right] \mathrm{Br}_{2} \cdot 2 \mathrm{H}_{2} \mathrm{O}$ : потеря воды происходит в интервале $40-103{ }^{\circ} \mathrm{C}$, и обезвоженный комплекс претерпевает эндотермическое превращение без потери массы, а затем при $162{ }^{\circ} \mathrm{C}$ теряет одну молекулу tn. Это создает предпосылки получения веществ с различным количеством координированного tn или их смеси в очень узких условиях синтеза, что мы наблюдали в работе [64]. Комплексы, содержащие циклообразующие лиганды (этилендиамин, пропилендиамин) представляют собой смесь оптических изомеров (энантиомер) за счет изменения ориентации и изменений конформаций хелатных колец.

Сведения, кратко изложенные в разделе 1 , свидетельствуют о том, что, во-первых, не существует видимой взаимосвязи термической устойчивости катионных комплексов и их термодинамической устойчивости, во-вторых, разложение этих комплексов всегда начинается с потери нейтральных лигандов с постепенным понижением числа координированных групп, но никогда не начинается с потери внешнесферных анионов. При этом природа газовой среды, в которой производится термолиз, не оказывает влияния на эту последовательность, а только на природу конечных продуктов термолиза: оксиды или галогениды ц.и. или ц.и.свободные металлы, и молекулы лигандов как таковые или продукты их окисления.

\section{2. Термолиз анионных комплексов}

Анионные комплексы представляют собой ацидокомплексы, т.е. лигандами, образующими их, являются кислотные остатки. Далеко не все они обеспечивают устойчивость комплексов и постоянный состав при нормальных условиях. Повидимому, не представляет большого интереса исследование термического поведения соединения, не обладающего хотя бы относительной стабильностью в обычных условиях (от нескольких часов до нескольких суток при комнатной температуре). Галогенид-ионы дают устойчивые комплексы только с благородными металлами, ртутью и свинцом. Цианид, тиоцианат, нитрит- и оксалат-ионы позволяют получить устойчивые ацидокомплексы $\mathrm{d}^{5}$ $\mathrm{d}^{10}$ переходных металлов и некоторых р-металлов. Соответственно, здесь рассмотрены комплексы с этими ацидолигандами. Другие случаи редки. В связи с высказанными выше соображениями приводим величины констант устойчивости комплексов, которые удалось найти в литературе: цианидных и оксалатных комплексов $\mathrm{Fe}(\mathrm{III})\left(10^{31}\right.$ и $\left.1,6 \cdot 10^{21}\right)$ и $\mathrm{Co}(\mathrm{III})\left(\sim 10^{64}\right.$ и $\left.10^{28}\right)$, а также $\left[\mathrm{Cr}(\mathrm{NCS})_{6}\right]^{3-}\left(10^{4}\right)$ [47]. На рис. 5 представлены кривые ТГ этих анионных комплексов в атмосфере воздуха. В современной литературе трудно найти работы, посвященные отдельно анионным комплексам ПМ, скорее эти сведения приводятся в работах, посвященных соответствующим ДКС, некоторые из которых описаны в нашем предыдущем обзоре [65]. В монографии [66] показано, что в области низких температур (до $200{ }^{\circ} \mathrm{C}$ ) для комплексов ПМ характерны такие превращения, как цис-транс- изомеризация диаминов, нитро-нитрито-изомеризация связи в координированной нитрогруппе и перегруппировка в солях типа Магнуса и Вокелена 


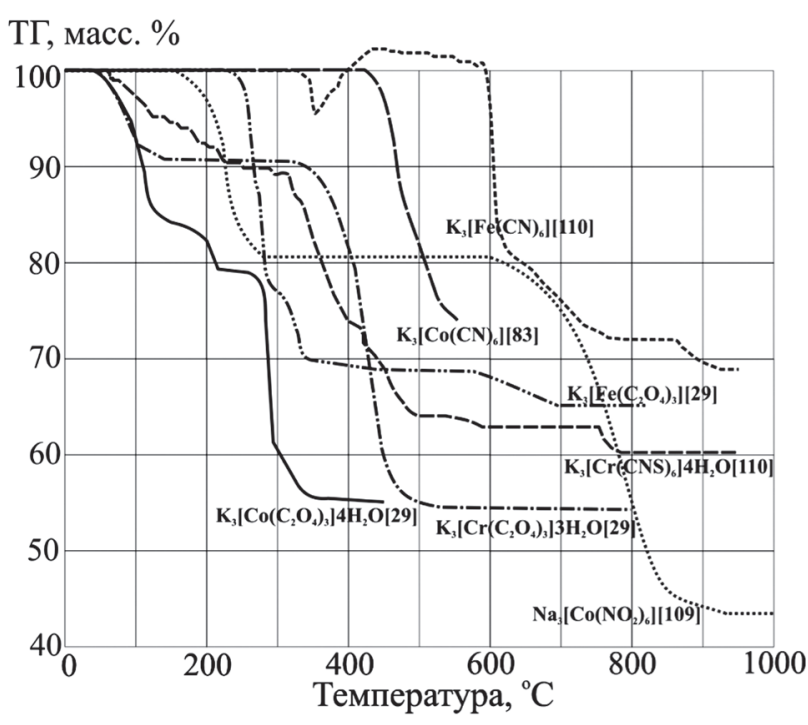

Рис. 5. Кривые термического анализа (ТГ) анионных комплексов на воздухе

с образованием диаминов, которые мы здесь отдельно не рассматриваем.

Ормонтом и Петровым [67-69] показано, что при красном калении в инертном газе желтая кровяная соль разлагается с образованием $\mathrm{KCN}$, $\mathrm{FeC}_{2}$ и азота, и это явление положено в основу технологического метода получения цианида калия. В вакууме получается также металлический калий и дициан. При термическом разложении красной кровяной соли образуется желтая кровяная соль. Бинарные цианиды железа, меди, кобальта и никеля [70-72] следует рассмотреть здесь, т.к. они легко переходят в циклические соединения и анионные формы.

Водный цианид Со разлагается с потерей воды при 125-200 ${ }^{\circ} \mathrm{C}$, потерей половины цианид -ионов при 400-470 ${ }^{\circ} \mathrm{C}$ в виде дициана и образованием смеси кобальта и углерода с выделением свободного азота до $570{ }^{\circ} \mathrm{C}$. Водный цианид никеля содержит при $240{ }^{\circ} \mathrm{C}$ еще остатки воды, а при $420{ }^{\circ} \mathrm{C}$ образует смесь никеля с углеродом и выделяет свободный азот. Дициан при этом не образуется [71]. Термолиз дицианида меди в атмосфере азота подробно изучен в связи с тем, что он используется для синтеза сверхпроводника $\mathrm{YBa}_{2} \mathrm{Cu}_{3} \mathrm{O}_{7}$ [72]. $\mathrm{Cu}_{2}(\mathrm{CN})_{2}$ полностью разлагается на медь и дициан в интервале $400-850{ }^{\circ} \mathrm{C}$. Процесс термолиза протекает через промежуточные стадии полимеризации исходного вещества в кольцевые структуры, плавления последних и разложения их. Работа [72] содержит обширные результаты ИКспектрометрического исследования промежуточных продуктов термолиза.

В работах [73-95] описан термолиз различных цианокомплексов с противоионами: щелочнозе- мельными металлами, кобальтом, никелем, аммонием, щелочными металлами, лантанидами [8592] и цветными металлами [93-95]. При наличии во внешней сфере лития, кальция или бария кристаллизационная вода при термолизе гексацианометаллатов удаляется от 80 до $180{ }^{\circ} \mathrm{C}$. Реакции эндотермические, во всех случаях отщепляется дициaн, соединения $\mathrm{Fe}(\mathrm{III})$ разлагаются при значительно более низких температурах, чем кобальта [73]. $\mathrm{H}_{3}\left[\mathrm{Co}(\mathrm{CN})_{6}\right]$ и $\left(\mathrm{NH}_{4}\right)_{3}\left[\mathrm{Co}(\mathrm{CN})_{6}\right]$ разлагаются путем сильно эндотермической реакции с отщеплением 3 моль $\mathrm{HCN}\left(225^{\circ} \mathrm{C}\right)$ или одновременно с этим еще 3 моль $\mathrm{NH}_{3}\left(330{ }^{\circ} \mathrm{C}\right)$ с образованием при этом $\mathrm{Co}\left[\mathrm{Co}(\mathrm{CN})_{6}\right]$, устойчивого до $400{ }^{\circ} \mathrm{C}$ и разлагающегося далее с отщеплением дициана [75]. Термолиз ДКС с анионом $\left[\mathrm{Co}(\mathrm{CN})_{6}\right]^{3-}$ см. в разделе 3. При разложении $\left(\mathrm{NH}_{4}\right)_{2}\left[\mathrm{Fe}(\mathrm{CN})_{5} \mathrm{NO}\right]$ эндоэффект от отщепления лигандов перекрывается экзоэффектом от отщепления NO [74].

Подробно изучено поведение при нагревании на воздухе красной и желтой кровяных солей [76-79]. $\mathrm{K}_{3}\left[\mathrm{Fe}(\mathrm{CN})_{6}\right]$ при нагревании до $200^{\circ} \mathrm{C}$ медленно превращается в $\mathrm{K}_{4}\left[\mathrm{Fe}(\mathrm{CN})_{6}\right]$, а при $250^{\circ} \mathrm{C}$ и выше полностью превращается в поташ и $\gamma-\mathrm{Fe}_{2} \mathrm{O}_{3}$ [76]. $\mathrm{K}_{4}\left[\mathrm{Fe}(\mathrm{CN})_{6}\right]$ устойчив на воздухе до $200{ }^{\circ} \mathrm{C}$, а затем при $250{ }^{\circ} \mathrm{C}$ также превращается в поташ и $\gamma-\mathrm{Fe}_{2} \mathrm{O}_{3}$ [77]. Было изучено влияние внешнесферных катионов (Co, Ni, Zn) на термическое поведение солей $\mathrm{M}_{2}\left[\mathrm{Fe}(\mathrm{CN})_{6}\right] \cdot \mathrm{H}_{2} \mathrm{O}[78]$, которые выдерживают нагревание до $100{ }^{\circ} \mathrm{C}$ без изменения мессбауэровского спектра, дегидратируются при $200{ }^{\circ} \mathrm{C}$ и начинают разлагаться при $250{ }^{\circ} \mathrm{C}$. Конечными продуктами термолиза на воздухе этих солей являются ферриты $\mathrm{MFe}_{2} \mathrm{O}_{4}+\mathrm{MO}$. Исходные соединения в ИК-спектрах имеют широкие полосы поглоще-

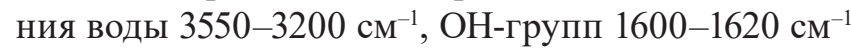
и для группы CN 2080, 2070 и $2090 \mathrm{~cm}^{-1}$ у соединений $\mathrm{Co}, \mathrm{Ni}$ и $\mathrm{Zn}$, соответственно. При потере воды положение полос в ИК-спектре не изменяется, снижается лишь интенсивность полос. Авторы [78] считали, что при термолизе на воздухе кобальт, никель и цинк сначала образуют оксиды, которые затем взаимодействуют с анионом $\left[\mathrm{Fe}(\mathrm{CN})_{6}\right]^{4-}$, образуя ферриты. В ходе реакции во всех трех случаях выделяется дициан. При окислительном термолизе $\mathrm{K}_{4}\left[\mathrm{Fe}(\mathrm{CN})_{6}\right] \cdot 3 \mathrm{H}_{2} \mathrm{O}$ образуются $\mathrm{K}_{4} \mathrm{Fe}(\mathrm{CN})_{6}$, $\alpha-\mathrm{Fe}_{2} 0_{3}, \mathrm{Fe}_{3} \mathrm{O}_{4}, \mathrm{Fe}_{3} \mathrm{C}, \mathrm{Fe}, \mathrm{FeO}, \mathrm{KFeO}_{2}, \beta-\mathrm{FeOOH}$, $\mathrm{KOCN}, \mathrm{K}_{2} \mathrm{CO}_{3}$ and $\mathrm{KCN}$ [82].

Интересно сопоставить работы [80, 81], посвященные термолизу $\mathrm{K}_{3}\left[\mathrm{Fe}(\mathrm{CN})_{6}\right]$ и ДКС в инертной среде, соответственно, гелия, аргона и азота. В 1988 г. [80] считали, что красная кровяная соль при нагревании сразу распадается на цианиды калия и железа(II) с выделением дициана, что было опровергнуто работой [81]. Авторами [80] было 
показано, что твердыми продуктами термолиза являются сначала $\mathrm{K}_{4}\left[\mathrm{Fe}(\mathrm{CN})_{6}\right]$ и $\mathrm{Fe}_{2}\left[\mathrm{Fe}(\mathrm{CN})_{6}\right]$ с выделением дициана, а затем цианид калия, цементит, углерод, азот и дициан. Для анализа твердой фазы [80] использованы рентгенодифракционный и мессбауэровский методы анализа, а для анализа газовых продуктов - газовая хроматография. В работе [81] были использованы методы рентгенодифракционного и химического анализа твердого остатка, а для газовых продуктов - ИК-спектрометрический метод. Было установлено, что продуктами термолиза $\mathrm{K}_{3}\left[\mathrm{Fe}(\mathrm{CN})_{6}\right]$ при $350{ }^{\circ} \mathrm{C}$ являются $\mathrm{K}_{4}\left[\mathrm{Fe}(\mathrm{CN})_{6}\right]$ и $\mathrm{Fe}_{4}\left[\mathrm{Fe}(\mathrm{CN})_{6}\right]_{3}$, и 0,5 моля дициана, при $670{ }^{\circ} \mathrm{C}-$ $\mathrm{KCN}, \quad \mathrm{Fe}_{4}\left[\mathrm{Fe}(\mathrm{CN})_{6}\right]_{3}$, железо, углерод и азот. При дальнейшем нагревании выделяется еще дициан, $\mathrm{Fe}_{3} \mathrm{C}$, углерод, и $\mathrm{KCN}$, который уже заметно испаряется при $900{ }^{\circ} \mathrm{C}$. $\mathrm{Fe}_{3} \mathrm{C}$ распадается и твердыми продуктами при $1000{ }^{\circ} \mathrm{C}$ остаются $\mathrm{KCN},+\mathrm{Fe}_{3} \mathrm{C}$ $+\mathrm{Fe}+\mathrm{C}$.

Результаты работы [81] были также подтверждены исследователями [83] на примере желтой и красной кровяных солей, $\mathrm{K}_{3}\left[\mathrm{Co}(\mathrm{CN})_{6}\right]$ и $\mathrm{K}_{2}\left[\mathrm{Hg}(\mathrm{CN})_{4}\right]$. Было показано, что для цианидных комплексов распад на простые цианиды при окислении в области температур до $500{ }^{\circ} \mathrm{C}$ не происходит. При окислении лигандов и наличии редокс-реакции ц.и., связанной с потерей массы, вероятно выделение дициана, как для гексацианокобальт(железо) (III) и $\mathrm{K}_{2}\left[\mathrm{Hg}(\mathrm{CN})_{4}\right]$. Изучению природы газообразных продуктов термолиза $\mathrm{K}_{2} \mathrm{Co}\left[\mathrm{Fe}(\mathrm{CN})_{6}\right] \cdot 1,4 \mathrm{H}_{2} \mathrm{O}$ в атмосфере воздуха между 240 и $360{ }^{\circ} \mathrm{C}$ посвящена работа [84]. Определение газов выполняли методом ИК-спектрометрии. Оказалось, что количество выделенного $\mathrm{CO}_{2}$ точно соответствует количеству углерода в исходном комплексе*, однако общее количество азота в азотсодержащих газах было только 39 \% от исходного. Предполагается, что остальные 61 \% азота выделяется в виде $\mathrm{N}_{2}$, который не может быть зафиксирован ИКСметодом. Поскольку соединение не содержит другого водорода, кроме как в воде, водород в аммиаке появляется, как считают авторы [84], из воды, которая конденсируется на стенках трубки между печью и ячейкой детектора газов.**

Большая группа работ [85-92] посвящена термическим свойствам гексацианометаллатов р.з.э. $\mathrm{Ln}\left[\mathrm{M}(\mathrm{CN})_{6}\right] \cdot \mathrm{nH}_{2} \mathrm{O}$, где $\mathrm{Ln}=\mathrm{La} \rightarrow \mathrm{Lu}, \mathrm{M}=\mathrm{Fe}, \mathrm{Co}, \mathrm{Cr}$. $\mathrm{B}$ результате термолиза этих соединений образу-

\footnotetext{
* Количества выделяющихся газов вычисляли по площади под кривой зависимости концентрации газа от температуры в системе.

** Водород, безусловно, из воды, но предположение относительно конденсированной воды кажется неубедительным.
}

ются орторомбические структуры типа перовскита $\mathrm{LnMO}_{3}$ Температуры образования перовскитов от 800 до $1100{ }^{\circ} \mathrm{C}$, возрастают с уменьшением радиусов атомов лантанидов. Промежуточные продукты содержат карбонаты. Газообразными продуктами термолиза являются $\mathrm{HCN}, \mathrm{NO}$ и $\mathrm{CO}_{2}$.

В работах [93-95] методом соосаждения синтезированы соединения-аналоги молекулярные магниты $\mathrm{K}_{0,8} \mathrm{Ni}_{1,1}\left[\mathrm{Fe}(\mathrm{CN})_{6}\right] \cdot 4,5 \mathrm{H}_{2} \mathrm{O}, \mathrm{Cu}_{1,5}\left[\mathrm{Fe}(\mathrm{CN})_{6}\right] \cdot 6 \mathrm{H}_{2} \mathrm{O}$ и $\mathrm{K}_{0,2} \mathrm{Co}_{1,4}\left[\mathrm{Fe}(\mathrm{CN})_{6}\right] \cdot 7 \mathrm{H}_{2} \mathrm{O}$ и исследовано их термическое разложение в атмосфере аргона. При нагревании ферромагнитные комплексы превращаются в парамагнитные в связи с изменением характера мостиковых связей: $\mathrm{Fe}^{\mathrm{III}}-\mathrm{CN}-\mathrm{Ni}^{\mathrm{II}}(\mathrm{Co}, \mathrm{Cu}) \rightarrow(\mathrm{Cu}, \mathrm{Ni})$ $\mathrm{Co}^{\mathrm{II}}-\mathrm{CN}-\mathrm{Fe}^{\mathrm{III}}$. Соединения имеют гранецентрированную кубическую структуру с константой ячейки около $10 \AA . \mathrm{K}_{0,8} \mathrm{Ni}_{1,1}\left[\mathrm{Fe}(\mathrm{CN})_{6}\right] \cdot 4,5 \mathrm{H}_{2} \mathrm{O}$ разлагается около $550{ }^{\circ} \mathrm{C}$ с образованием твердого раствора $\mathrm{NiFe}$ кубической гранецентрированной структуры и аморфного углерода; $\mathrm{K}_{0,2} \mathrm{Co}_{1,4}\left[\mathrm{Fe}(\mathrm{CN})_{6}\right] \cdot 7 \mathrm{H}_{2} \mathrm{O}$ разлагается при $300{ }^{\circ} \mathrm{C}$ с образованием аналогичной системы $\left(25\right.$ масс. \% C), и $\mathrm{Cu}_{1,5}\left[\mathrm{Fe}(\mathrm{CN})_{6}\right] \cdot 6 \mathrm{H}_{2} \mathrm{O}$ разлагается около $370{ }^{\circ} \mathrm{C}$. Надо заметить, что $\mathrm{NiFe}$ остаток от прокаливания содержит 14 масс. \% C, а в интервале $600-800{ }^{\circ} \mathrm{C}$ в нем существует метастабильная фаза $\mathrm{CuFe}$. Аналогичное исследование $\mathrm{Ni}_{1,5}\left[\mathrm{Fe}(\mathrm{CN})_{6}\right] \cdot 10 \mathrm{H}_{2} \mathrm{O}$ описано в работе [81], однако результаты несколько иные, чем в работе [93]. Так, при $250{ }^{\circ} \mathrm{C}$ соединение диспропорционирует на $\mathrm{Ni}_{2}\left[\mathrm{Fe}(\mathrm{CN})_{6}\right] \cdot 2 \mathrm{H}_{2} \mathrm{O}$ и $\mathrm{Fe}_{4}\left[\mathrm{Fe}(\mathrm{CN})_{6}\right]_{3}$, при 620 и $800{ }^{\circ} \mathrm{C}$ найдены остатки от прокаливания, состоящие из интерметаллидов $\mathrm{NiFe}$ и $\mathrm{Ni}_{3} \mathrm{Fe}$. При $800^{\circ} \mathrm{C}$ в остатке содержится $37,5 \%$ С от исходного содержания. Принимая во внимание данные работ [80, 81, 93-95], можно считать, что для цианометаллатов характерно, что при нагревании в инертной атмосфере координированные цианогруппы разлагаются с выделением свободного азота и углерода.

В работах [96-99] исследованы нетипичные случаи термолиза цианокомплексов, например, термолиз соединения с катионом, обладающим восстановительными свойствами $(\mathrm{VO})_{2}\left[\mathrm{Fe}(\mathrm{CN})_{6}\right] \cdot 10 \mathrm{H}_{2} \mathrm{O}$, который разлагается с выделением дициана и циановодорода и образованием в твердой фазе смеси железа и $\mathrm{VO}_{2}$ [96]. Реакция термолиза $\mathrm{Ag}_{4}\left[\mathrm{Fe}(\mathrm{CN})_{6}\right]$ [97] предлагается для аналитического применения. Для получения триметаллических оксидных материалов предложены реакции термолиза $\mathrm{Bi}\left[\mathrm{Fe}_{\mathrm{x}} \mathrm{Co}_{1-\mathrm{x}}(\mathrm{CN})_{6}\right][98]$ и $\mathrm{K}_{2-\mathrm{x}} \mathrm{Ni}_{\mathrm{x} / 2}\left[\mathrm{NiFe}(\mathrm{CN})_{6}\right] \cdot \mathrm{nH}_{2} \mathrm{O}$ [99]. Статья [100] принадлежит к числу редких работ, где рассмотрен термолиз комплекса в атмосфере водорода. $\mathrm{K}_{3}\left[\mathrm{Co}(\mathrm{CN})_{5} \mathrm{~L}\right] \cdot \mathrm{nH}_{2} \mathrm{O}$ разлагается в три стадии: отщепление внешнесферной воды, отщепление L и разложение образовавшегося 
$\mathrm{K}_{3}\left[\mathrm{Co}(\mathrm{CN})_{6}\right]$ до $\mathrm{KCN},(\mathrm{CN})_{2}$, затем $\mathrm{HCN}, \mathrm{N}_{2}, \mathrm{NH}_{3}$, $\mathrm{Co}_{3} \mathrm{C}$, и при $>550{ }^{\circ} \mathrm{C} \mathrm{Co}+\mathrm{CH}_{4}$.

Помимо публикаций, посвященных цианокомплексам, были найдены работы по изучению термолиза оксалатных комплексов [29, 101-107], гексанитрокобальтата $[108,109]$ и роданидного комплекса [110]. Согласно [29], термическая устойчивость $\mathrm{K}_{3}\left[\mathrm{M}(\mathrm{Ox})_{3}\right] \cdot \mathrm{nH}_{2} \mathrm{O}$ зависит от природы M следующим образом: $\mathrm{Cr}>\mathrm{Fe}, \mathrm{Co}$, хотя константа устойчивости комплекса Со значительно выше, чем железа. Основная потеря массы для комплексов кобальта и железа приходится на интервал температур 200-300 ${ }^{\circ} \mathrm{C}$, тогда как у весьма термодинамически неустойчивого роданидного комплекса на интервал $300-400{ }^{\circ} \mathrm{C}$ (рис. 5). Такая же последовательность термической устойчивости получена и в работе [101] для комплексов хрома, железа и кобальта. Авторы [101] утверждают, что термическое разложение инициируется переносом электрона с лиганда на ц.и. Таким образом, при одном и том же координированном лиганде наименее термически устойчив будет тот комплекс, ц.и. которого является наиболее сильным окислителем (здесь $\mathrm{Co}>\mathrm{Fe}>>\mathrm{Cr}$ ). Конечным продуктом термолиза (трис)-оксалатного комплекса $[102,104]$ на воздухе является $\mathrm{Fe}_{2} \mathrm{O}_{3}$, а если во внешней сфере есть калий - то с примесью оксалата $\left(260^{\circ} \mathrm{C}\right)$ и карбоната калия $\left(380^{\circ} \mathrm{C}\right)$, а при $580{ }^{\circ} \mathrm{C}-$ феррат(III) калия. Область термической устойчивости как в [29, 101]. Обнаружено [103], что на воздухе при $260^{\circ} \mathrm{C}$ образуется биядерный интермедиат $\mathrm{K}_{6} \mathrm{Fe}_{2}{ }_{2}{ }_{2}\left(\mathrm{C}_{2} \mathrm{O}_{4}\right)_{5}$ с выделением $\mathrm{CO}_{2}$, где ионы железа соединены тетрадентатной оксалатогруппой. Конечный продукт свыше $500{ }^{\circ} \mathrm{C}$ представляет собой смесь $\mathrm{Fe}_{2} \mathrm{O}_{3}$ и поташа. В вакууме вместо оксида образуется металлическое железо. Аналогичное исследование (трис)-оксалатокобальтатов щелочноземельных элементов и аммония [105] показало, что в атмосфере воздуха и $\mathrm{CO}_{2}$ и в вакууме соединения разлагаются ступенчато, дегидратация начинается от $300{ }^{\circ} \mathrm{C}$, затем разлагается оксалат с выделение $\mathrm{CO}_{2}$ и образуются оксалаты двухвалентных металлов и кобальта. При $900{ }^{\circ} \mathrm{C}$ образуется карбонат бария и $\mathrm{Co}_{3} \mathrm{O}_{4}$. В числе газовых продуктов наблюдается $\mathrm{CO}$, соотношение $\mathrm{CO}: \mathrm{CO}_{2} \sim 1: 1,5$. В работе [107] проведено сравнительное изучение термолиза (трис)-оксалатных комплексов хрома, алюминия и железа и (бис)-оксалатокупрата калия в зависимости от скорости нагрева. Состав газообразных продуктов термолиза изучен методом газовой хроматографии, правда, для простых, а не комплексных оксалатов железа [106]. Это СО, $\mathrm{CO}_{2}$, метан.

Термическая диссоциация гексанитрокобальтатов описана в работах $[108,109]$ Установлено, что природа внешнесферного катиона щелочного металла сильно влияет на термическую стойкость соединения за счет поляризующего действия катиона на анион. Установлено, что природа внешнесферного катиона - щелочного металла сильно влияет на термическую стойкость $\mathrm{M}_{3}\left[\mathrm{Co}\left(\mathrm{NO}_{2}\right)_{6}\right]$ [109]. Приводится уравнение реакции разложения в области температур до $800{ }^{\circ} \mathrm{C}$ [108]:

$$
\begin{aligned}
& 3 \mathrm{Na}_{3}\left[\mathrm{Co}\left(\mathrm{NO}_{2}\right)_{6}\right]_{(\text {(тв) }} \rightarrow \\
& \rightarrow 9 \mathrm{NaNO}_{2(\text { (тв) }}+\mathrm{CO}_{3} \mathrm{O}_{4(\mathrm{rв})}+5 \mathrm{NO}_{2(\text { (г) }}+4 \mathrm{NO}_{(\mathrm{r})}
\end{aligned}
$$

Однако за счет диссоциации нитрита натрия можно ожидать образования также оксида натрия.

Рис. 5 позволяет нам сравнить термическое поведение анионных комплексов. Видно, что только цианидные комплексы железа и кобальта сохраняют свой исходный состав до $\sim 400{ }^{\circ} \mathrm{C}$, при этом около $350{ }^{\circ} \mathrm{C} \mathrm{K}_{3}\left[\mathrm{Fe}(\mathrm{CN})_{6}\right]$ отщепляет 0,5 моля дициана. Разложение остальных комплексов начинается уже от $60-70{ }^{\circ} \mathrm{C}$ и интенсивно протекает до $\sim 200{ }^{\circ} \mathrm{C}$, что относится непосредственно к разложению комплекса. Процессы, происходящие при более высоких температурах, следует считать реакциями промежуточных продуктов прокаливания комплексов. Как уже отмечено выше, первая большая потеря массы для оксалатных комплексов связана с отщеплением первой оксалатогруппы, а вторая - с разложением интермедиата. Практически одинаковая устойчивость оксалатных комплексов кобальта и железа связана, очевидно, с восстановлением Сo(III) до Сo(II), в результате чего влияние термодинамической устойчивости нивелируется. $\mathrm{Na}_{3}\left[\mathrm{Co}\left(\mathrm{NO}_{2}\right)_{6}\right]$, разлагаясь около $230{ }^{\circ} \mathrm{C}$, далее сохраняет постоянную массу до $650{ }^{\circ} \mathrm{C}$, когда нитрит натрия переходит в оксид ${ }^{* * *}$. Остаток от прокаливания роданидного комплекса близок к $58 \%$, которые соответствуют остатку состава $3 \mathrm{~K}_{2} \mathrm{SO}_{4}+\mathrm{Cr}_{2} \mathrm{O}_{3}$ [110], который образуется в области $750{ }^{\circ} \mathrm{C}$. Последние два примера особенно подчеркивают, что в области высоких температур процессы уже не связаны со структурой исходного комплекса.

Итак, мы все более убеждается, что взаимосвязь между термодинамической и термической устойчивостью комплекса практически отсутствует. В противоположность термолизу катионных комплексов, природа газовой среды для термолиза анионных комплексов имеет очень большое значение, и тем большее, чем сложнее координированные лиганды. В атмосфере воздуха интересующие нас лиганды $\left(\mathrm{CN}^{-}, \mathrm{C}_{2} \mathrm{O}_{4}^{2-}, \mathrm{NO}_{2}^{-}\right)$главным образом окисляются (сгорают) с образованием $\mathrm{CO}_{2}$, $\mathrm{N}_{2}$ и оксидов азота. Металл ц.и. образует оксиды,

\footnotetext{
*** чистый нитрит натрия разлагается при $320^{\circ} \mathrm{C}$.
} 
как и в случае катионных соединений. В инертной среде процесс разложения значительно усложняется: наблюдается образование карбидов ц.и., оксалатов и карбонатов и значительных количеств свободного углерода. К сожалению, нам не удалось найти в литературе достаточно обширных сведений о поведении анионных комплексов в восстановительной среде $\left(\mathrm{H}_{2}\right)$.

\section{3. Термолиз двойных комплексных соединений}

Как подчеркнуто выше, двойное комплексное соединение состоит из комплексного катиона и комплексного аниона; такое строение должно сильно усложнять процесс термолиза ДКС. Вероятно, процесс термической деструкции ДКС должен сочетать в себе особенности термического разложения составляющих его катионных и анионных монокомплексов, за исключением некоторых стадий.

Вначале рассмотрим термическое разложение самого старого, известного с 1704 г. цианокомплек$\mathrm{ca}$ - берлинской лазури (Prussian blue, PB). РВ представляет собой нечто среднее между анионным комплексом и ДКС, так как она содержит аквакомплексы Fe(III), и ее формула может быть представлена как $\left[\mathrm{Fe}_{4}\left(\mathrm{H}_{2} \mathrm{O}\right)_{\mathrm{x}}\right]\left[\mathrm{Fe}(\mathrm{CN})_{6}\right]_{3}$, где $\mathrm{x}=14-15$ в [70] и 4 в работе [111]. Степень гидратации $\mathrm{PB}$ очень зависит от температуры и влажности. При нагревании на воздухе до $150{ }^{\circ} \mathrm{C} 90 \%$ воды обратимо удаляется [112]. На основании работ [70, 111, 112] можно представить термолиз РВ в инертной среде следующим образом. Соединение показывает 4 стадии разложения. На первой стадии при $67-262{ }^{\circ} \mathrm{C}$ происходит потеря массы 7,6 \%, что соответствует отщеплению 4 молекул воды. При температуpe $120{ }^{\circ} \mathrm{C}$ происходит частичное восстановление железа в катионной части до $\mathrm{Fe}(\mathrm{II})$ с образованием $\mathrm{Fe}_{2}{ }^{\mathrm{III}} \mathrm{Fe}{ }^{\mathrm{II}}\left[\mathrm{Fe}(\mathrm{CN})_{6}\right]_{2}$ и частичным отщеплением $(\mathrm{CN})_{2}$. На втором этапе в интервале $262-377^{\circ} \mathrm{C}$ теряется 14,7\% массы, происходит удаление 6 цианогрупп в виде 3 молекул $(\mathrm{CN})_{2}$ и образуется смесь $\mathrm{Fe}_{4}\left[\mathrm{Fe}(\mathrm{CN})_{6}\right]_{3}$ и $\mathrm{Fe}_{3}\left[\mathrm{Fe}(\mathrm{CN})_{6}\right]_{2}$. $\mathrm{Fe}_{3}\left[\mathrm{Fe}(\mathrm{CN})_{6}\right]_{2}$ при нагревании до $205^{\circ} \mathrm{C}$ разлагается до $\mathrm{Fe}{ }_{2}\left[\mathrm{Fe}(\mathrm{CN})_{6}\right]$, который при $405{ }^{\circ} \mathrm{C}$ деполимеризуется до простого $\mathrm{Fe}(\mathrm{CN})_{2}$.

При повышении температуры до $707^{\circ} \mathrm{C}$ удаляется 23,0 \% массы и происходит полное разложение оставшихся продуктов на различные полиморфные формы карбидов железа, включая $\mathrm{Fe}_{7} \mathrm{C}_{3}, \mathrm{Fe}_{2} \mathrm{C}$ и графит. Отмечается выделение не только дициана, но и $\mathrm{N}_{2}$. На четвертой стадии при $707-1000{ }^{\circ} \mathrm{C}$ происходит превращение образовавшихся карбидов железа в цементит, $\alpha$ и $\gamma-\mathrm{Fe}$ и графит. Таким образом, суммарное уравнение реакции термиче- ского разложения берлинской лазури в инертной среде [111]:

$$
\begin{aligned}
& \mathrm{Fe}_{4}\left[\mathrm{Fe}(\mathrm{CN})_{6}\right]_{3} \cdot 4 \mathrm{H}_{2} \mathrm{O} \rightarrow \\
& \rightarrow 4 \mathrm{Fe}+\mathrm{Fe}_{3} \mathrm{C}+7 \mathrm{C}+5(\mathrm{CN})_{2}+4 \mathrm{~N}_{2}+4 \mathrm{H}_{2} \mathrm{O}
\end{aligned}
$$

Существующие данные по термолизу ДКС можно разделить на несколько направлений в зависимости от природы ц.и. С целью сравнения в дальнейшем очень коротко рассмотрим некоторые работы, посвященные разложению ДКС ПМ и золота. Исследованы различные сочетания металлов: $\mathrm{Pd}-\mathrm{Pt}$ [113-115], $\mathrm{Ru}-\mathrm{Pt} / \mathrm{Pd}$ [116], Rh - Pt [117], $\mathrm{Ir}-\mathrm{Pd} / \mathrm{Pt}[2,10,12,118], \mathrm{Ir} / \mathrm{Pd} / \mathrm{Pt} / \mathrm{Rh} / \mathrm{Ru}-\mathrm{Au}[119-$ 122], Os - Re [123], Ru - Pt/Ir/Re/Os [124-126] и др. В качестве лигандов использовался только аммиак или сочетание аммиака и Hal в катионной части комплекса и галогенид-ионы - в анионной. Продуктами термолиза в боьшинстве случаев являются металлы ц.и. в свободном состоянии. Термолиз проводили в инертной, воздушной и водородной (смесь Не и $\mathrm{H}_{2}$ ) средах. Использование водорода увеличивало скорость разложения как катионной, так и анионной частей ДКС, и снижало температуру окончания процесса; в случае гелия и воздуха термолиз зачастую протекал одинаково. Как было отмечено выше, для ДКС благородных металлов характерны различные внутримолекулярные перегруппировки на начальных стадиях термолиза. Газообразные продукты термолиза практически не рассматривались в работах $[2,10,12$, 113-126], только в работе [115] при $\sim 340{ }^{\circ} \mathrm{C}$ зафиксировано выделение $\mathrm{N}_{2}, \mathrm{H}_{2}, \mathrm{HBr}$ и $\mathrm{NH}_{3}$. При термолизе только родий $[117,121]$ в инертной среде способен в качестве продукта темолиза давать галогениды, а не выделяться в свободном состоянии.

Более подробно газообразные продукты рассмотрены в работе [125], в которой приведены кривые ТГ в сопровождении данных анализа отходящих газов для соединений $\left[\mathrm{Ru}\left(\mathrm{NH}_{3}\right)_{5} \mathrm{Cl}\right]\left[\mathrm{MCl}_{6}\right]$ $(\mathrm{M}=\mathrm{Pt}, \mathrm{Ir})$ в атмосфере гелия. Видно, что минимумы на кривых ДТГ и эндоэффекты на кривых ДСК совпадают с максимумами на кривых газовыделения в области температур около $350-395{ }^{\circ} \mathrm{C}$. Обнаружены следующие продукты: $\mathrm{HCl}$ (м.ч. 36), $\mathrm{N}_{2}$ (м.ч. 28), $\mathrm{NH}_{3}$ (м.ч. 17). Найдено, что в процессе термолиза Pt-содержащих солей в интервале от 260 до $\sim 300{ }^{\circ} \mathrm{C}$ образуется полимерное промежуточное соединение « $\left[\mathrm{Ru}^{\mathrm{III}}\left(\mathrm{NH}_{3}\right)_{3} \mathrm{Pt}^{\mathrm{IV}} \mathrm{Cl}_{7}\right] »$, а для Irсодержащих солей - в области $230-290{ }^{\circ} \mathrm{C}$ обнаружено «( $\left.\mathrm{NH}_{4}\right)_{0,65}\left[\mathrm{Ru}^{\mathrm{III}} \mathrm{II}^{\mathrm{III}}\left(\mathrm{NH}_{3}\right)_{4} \mathrm{Cl}_{6,65}\right] »[125]$.

Метод анализа отходящих газов также использован в работе [122], посвященной изучению ДКС с золотом в качестве ц.и. При помощи МС определены $\mathrm{N}_{2}, \mathrm{NH}_{3}, \mathrm{HCl}$ и $\mathrm{H}_{2} \mathrm{O}$. В соединениях 
$\left[\mathrm{M}\left(\mathrm{NH}_{3}\right)_{5} \mathrm{Hal}\right]\left[\mathrm{AuHal}_{4}\right]_{2} \cdot \mathrm{nH}_{2} \mathrm{O}(\mathrm{M}=\mathrm{Rh}, \mathrm{Ir}, \mathrm{Hal}=\mathrm{Cl}$, $\mathrm{Br})$ при термолизе в атмосфере Не уже в интервале 200-300 ${ }^{\circ} \mathrm{C}$ фиксируется металлическое $\mathrm{Au}$, а ПМ определяются в формах $\left[\mathrm{M}\left(\mathrm{NH}_{3}\right)_{5} \mathrm{Br}\right] \mathrm{Br}_{2}$ ( $\mathrm{M}=\mathrm{Rh}, \mathrm{Ir}),\left[\mathrm{Rh}\left(\mathrm{NH}_{3}\right)_{3} \mathrm{Br}_{3}\right]$. В случае ДКС с $\mathrm{Rh}$ в качестве газообразных продуктов методом МС обнаружены $\mathrm{N}_{2}, \mathrm{NH}_{3}$ и $\mathrm{Br}_{2}$. Конечными твердыми продуктами в атмосфере $\mathrm{H}_{2}$ являются двухфазные металлические системы, содержащие Au и Ir или Rh, в случае среды Не определены $\mathrm{Au}$ и $\mathrm{Au}_{0,05} \mathrm{Ir}_{0,95}$ или $\mathrm{RhBr}_{3}$. При термолизе в инертной атмосфеpe $\left[\mathrm{PtNH}_{3}\right)_{5} \mathrm{Cl}_{2}\left[\mathrm{AuCl}_{4}\right]_{2} \cdot 4 \mathrm{H}_{2} \mathrm{O}$ в области $200-270{ }^{\circ} \mathrm{C}$ также определяется смесь $\mathrm{Au}+\left[\mathrm{Pt}\left(\mathrm{NH}_{3}\right)_{4}\right] \mathrm{Cl}_{2}+$ $\left[\mathrm{Pt}\left(\mathrm{NH}_{3}\right)_{2} \mathrm{Cl}_{4}\right]$. Таким образом, до $300{ }^{\circ} \mathrm{C}$ редкие платиновые металлы (РПМ) еще не восстанавливаются.

При анализе твердого остатка от термолиза ДКС ПМ необходимо рассматривать термодинамическую диаграмму состояния бинарной системы металлов ц.и. Конечными продуктами для ПМсодержащих соединений во всех видах атмосфер являются: различные твердые растворы ц.и. с кубической или гексагональной упаковкой или мелкодисперсные смеси чистых металлов или сплавы [113-126]. Если в состав соединения входит платина или золото, они образуют металлическую фазу даже при термолизе на воздухе. При термолизе ДКС в водороде зачастую получаются твердые растворы [116-126], так как, во-первых, оба металла могут восстанавливаться одновременно и, во-вторых, восстановление происходит при относительно низких температурах, когда диффузия атомов сильно замедлена. Интересно, что эти растворы образуются при температурах, которые гораздо ниже температур плавления металлов самих по себе. Рутений из всех ПМ наиболее часто образует в качестве продукта термолиза соединения вместо металла [126].

Термолиз ДКС, содержащих $\mathrm{Pt}$ или $\mathrm{Pd}$ и один 3d-металл: $\left[\mathrm{M}\left(\mathrm{NH}_{3}\right)_{\mathrm{x}}\right]\left[\mathrm{PtHal}_{\mathrm{y}}\right] \cdot \mathrm{nH}_{2} \mathrm{O},(\mathrm{M}=\mathrm{Cu}[127$, 128], Ni [129], $\mathrm{x}=4,6, \mathrm{n}=0,0,5)$ и $\left[\mathrm{Co}\left(\mathrm{NH}_{3}\right)_{5} \mathrm{Cl}\right]$ $\left[\mathrm{MHal}_{4}\right](\mathrm{M}=\mathrm{Pt}, \mathrm{Pd})$ [118] разложения протекает аналогично рассмотренному выше. Разложение для всех соединений в атмосфере аргона и на воздухе начинается с удаления кристаллизационной воды. Затем в атмосфере воздуха может происходить отщепление части координированного аммиака - удаляется 2 молекулы из 6 в случае $\left[\mathrm{Ni}\left(\mathrm{NH}_{3}\right)_{6}\right]$ $\left[\mathrm{PtBr}_{6}\right]$; если соединение изначально содержит 4 молекулы аммиака, например $\left[\mathrm{Cu}\left(\mathrm{NH}_{3}\right)_{4}\right]\left[\mathrm{PtHal}_{6}\right]$, то никаких изменений состава не наблюдается. Затем у всех ДКС происходит перегруппировка лигандов (термоизомеризация), сопровождающаяся экзоэффектом при $\sim 200{ }^{\circ} \mathrm{C}$ и происходит разрушение ДКС с образованием двух монокомплексов $\left[\mathrm{M}\left(\mathrm{NH}_{3}\right)_{2} \mathrm{Hal}_{2}\right]$ и $\left[\mathrm{Pt}\left(\mathrm{NH}_{3}\right)_{2} \mathrm{Hal}_{4}\right]$. При дальней- шем нагревании комплексы $\mathrm{Ni}$ и $\mathrm{Cu}$ отщепляют 2 молекулы аммиака и атом Hal и превращаются сна-

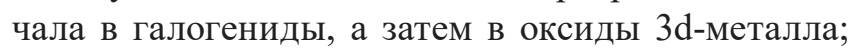
в случае меди также образуется примесь $\mathrm{Cu}_{2} \mathrm{O}$. Одновременно происходит диспропорционирование комплекса Pt, например:

$$
\begin{aligned}
& 5 \text { транс- }\left[\mathrm{Pt}\left(\mathrm{NH}_{3}\right)_{2} \mathrm{Br}_{4}\right]+5 \mathrm{Br}^{0}+\mathrm{NH}_{3} \rightarrow \\
& \rightarrow \mathrm{Pt}+4\left(\mathrm{NH}_{4}\right)_{2}\left[\mathrm{PtBr}_{6}\right]+\mathrm{HBr}+3 / 2 \mathrm{~N}_{2}
\end{aligned}
$$

В случае термолиза этих комплексов в инертной атмосфере [128, 129] конечными продуктами являются твердые растворы Pt-Ni или $\mathrm{Pt}-\mathrm{Cu}$ на основе $\mathrm{Pt}$. При термолизе $\left[\mathrm{Co}\left(\mathrm{NH}_{3}\right)_{6}\right]\left[\mathrm{AuX}_{4}\right] \mathrm{X}_{2}$, где $\mathrm{X}=\mathrm{Cl}^{-}, \mathrm{Br}^{-}[130]$ конечными продуктами термолиза являются: в атмосфере $\mathrm{H}_{2}$ порошки $\mathrm{Au}^{0}$ и $\mathrm{Co}^{0}$, в инертной среде - смесь $\mathrm{Au}^{0}$ и галогенида кобальта (II).

В работе [131] показано, что при восстановительном термолизе группы пентаядерных ДКС типа $\left[\mathrm{Pd}(\mu-\mathrm{OOCMe})_{4} \mathrm{M}\right]_{2}(\mu-\mathrm{OOCMe})_{2} \mathrm{Pd}(\mathrm{Py})_{2}, \quad$ где $\mathrm{M}=\mathrm{Ni}, \mathrm{Co}, \mathrm{Mn}, \mathrm{Zn}$ получаются следующие смеси наноразмерных частиц: $\mathrm{Pd}_{3} \mathrm{Ni}$ и $\mathrm{Pd}_{0,9} \mathrm{Ni}_{0,1}, \mathrm{Pd}_{0,7} \mathrm{Co}_{0,3}$ и $\mathrm{Pd}_{0,85} \mathrm{Co}_{0,15}$ и смеси $\mathrm{Pd}_{0,9} \mathrm{Zn}_{0,1}$ и $\mathrm{ZnO}, \mathrm{Pd}$ и $\mathrm{Mn}_{3} \mathrm{O}_{4}$, соответственно.

В ряде работ исследовано термическое разложение ДКС, в составе которых присутствует одновременно ПМ, Au или Ag и 3d-металл, но в качестве лигандов используются $\mathrm{NH}_{3}$ [132], en [133137], pn [137], оксалат-ион [138]. В результате термолиза таких ДКС в атмосфере воздуха образуются свободные ПМ, золото или серебро и оксиды 3d-металлов [134-137]; в инертной атмосфере также, если анион содержит кислород [138], в атмосфере, содержащей водород - смеси свободных металлов-ц.и. или их твердые растворы или интерметаллиды [118-127].

Перейдем к анализу публикаций, относящихся к термолизу ДКС, содержащим только 3d-металлы. Во всех случаях, когда в составе ДКС присутствуют цианометаллатные ионы, разложение катионной и анионной частей ДКС начинается одновременно (при одной и той же температуре).

В работах $[75,30]$ использованы наиболее простые лиганды. Работа [75] посвящена термолизу в аргоне ДКС вида $\left[\mathrm{Co}\left(\mathrm{NH}_{3}\right)_{6}\right]\left[\mathrm{M}(\mathrm{CN})_{6}\right](\mathrm{M}=\mathrm{Co}(\mathrm{III})$, $\mathrm{Fe}(\mathrm{II}, \mathrm{III}), \quad \mathrm{Cr}(\mathrm{III}), \quad \mathrm{Mn}(\mathrm{III})), \quad\left[\mathrm{Co}\left(\mathrm{NH}_{3}\right)_{6}\right]\left[\mathrm{Ni}(\mathrm{CN})_{4}\right]$, $\left[\mathrm{Co}\left(\mathrm{NH}_{3}\right)_{6}\right]\left[\mathrm{Mo}(\mathrm{CN})_{8}\right] \quad$ и $\quad\left[\mathrm{Co}\left(\mathrm{NH}_{3}\right)_{6}\right]\left[\mathrm{M}(\mathrm{CN})_{5} \mathrm{NO}\right]$ $(\mathrm{M}=\mathrm{Fe}(\mathrm{III}), \mathrm{Mn}(\mathrm{I}))$. Все ДКС показывают сильный эндоэффект в области $200-300{ }^{\circ} \mathrm{C}$, наиболее термически устойчив $\left[\mathrm{Co}\left(\mathrm{NH}_{3}\right)_{6}\right]\left[\mathrm{Co}(\mathrm{CN})_{6}\right]$, наименее - $\left[\mathrm{Co}\left(\mathrm{NH}_{3}\right)_{6}\right]\left[\mathrm{Mo}(\mathrm{CN})_{8}\right]$. Кривые ДТА для ДКС типа $\left[\mathrm{Co}\left(\mathrm{NH}_{3}\right)_{6}\right]\left[\mathrm{M}(\mathrm{CN})_{6}\right]$, где $\mathrm{M}=\mathrm{Co}, \mathrm{Fe}, \mathrm{Cr}, \mathrm{Mn}$, $\mathrm{Ni}$, Мо, очень похожи. В случае ДКС с $\mathrm{Ni}$ и $\mathrm{Cr}$ наблюдаются перегруппировки лигандов. Первый 
эндоэффект соответствует отщеплению аммиака из катиона. Далее везде присутствует экзоэффект в области $575{ }^{\circ} \mathrm{C}$, который авторы относят к отщеплению дициана. Предполагается, что происходят процессы, аналогичные термолизу $\left[\mathrm{Co}\left(\mathrm{NH}_{3}\right)_{6}\right]$ $\left[\mathrm{Co}(\mathrm{CN})_{6}\right][75]$. Кривые ДТА $\left[\mathrm{Co}\left(\mathrm{NH}_{3}\right)_{6}\right]\left[\mathrm{Co}(\mathrm{CN})_{6}\right]$ и $\left(\mathrm{NH}_{4}\right)_{3}\left[\mathrm{Co}(\mathrm{CN})_{6}\right]$ практически совпадают (с точностью до $5^{\circ}$ ), и образуются одинаковые промежуточные продукты термолиза, за счет постепенного удаления цианида, согласно схеме:

$$
\begin{gathered}
\left(\mathrm{NH}_{4}\right)_{3}\left[\mathrm{Co}(\mathrm{CN})_{6}\right] \stackrel{330^{\circ}}{\longrightarrow} \mathrm{Co}^{\mathrm{III}}\left[\mathrm{Co}^{\mathrm{III}}(\mathrm{CN})_{6}\right] \stackrel{415^{\circ}}{\longrightarrow} \\
\mathrm{Co}_{3}{ }^{\mathrm{II}}\left[\mathrm{Co}^{\mathrm{III}}(\mathrm{CN})_{6}\right]_{2} \stackrel{400^{\circ}}{\longrightarrow} \mathrm{Co}_{3}{ }_{3}^{\mathrm{II}}\left[\mathrm{Co}_{2}{ }^{\mathrm{II}}(\mathrm{CN})_{10}\right]
\end{gathered}
$$

Выше $500{ }^{\circ} \mathrm{C}$ происходит деполимеризация $\mathrm{Co}_{3}\left[\mathrm{Co}_{2}(\mathrm{CN})_{10}\right]$ с образованием простого цианида $\mathrm{Co}(\mathrm{II})$, который около $600^{\circ} \mathrm{C}$ превращается сначала в цианид $\mathrm{Co}(\mathrm{I})$, и затем в металлический Сo. В качестве газообразных продуктов для $\left(\mathrm{NH}_{4}\right)_{3}\left[\mathrm{Co}(\mathrm{CN})_{6}\right]$ определены дициан, $\mathrm{NH}_{3}$ и $\mathrm{HCN}$ [75].

Исследование термолиза $[\mathrm{M}(\mathrm{en})]\left[\mathrm{M}^{\prime}(\mathrm{CN})_{4}\right]$ $\left(\mathrm{M}=\mathrm{Cd}(\mathrm{II}), \mathrm{Mn}(\mathrm{II}) ; \mathrm{M}^{\prime}=\mathrm{Ni}(\mathrm{II}), \mathrm{Cd}(\mathrm{II})\right)$ на воздухе проведено в [139]. Процесс разложения имеет экзотермический характер и происходит в широком интервале температур $250-500{ }^{\circ} \mathrm{C}$, только в случае ДКС Сd-Сd наблюдается эндоэффект при 150 $250{ }^{\circ} \mathrm{C}$. Сначала удаляется весь еn и имеет место промежуточное образование $\mathrm{Cd}(\mathrm{CN})_{2}, \mathrm{CdNi}(\mathrm{CN})_{4}$, $\mathrm{MnNi}(\mathrm{CN})_{4}, \mathrm{MnCd}(\mathrm{CN})_{4}$. Конечный продукт разложения - смеси простых и сложных оксидов ц.и.

Разложение $\left[\mathrm{M}(\mathrm{en})_{3}\right]\left[\mathrm{M}^{\prime}(\mathrm{CN})_{5} \mathrm{NO}\right] \cdot \mathrm{nH}_{2} \mathrm{O} \quad[140]$ $\mathrm{M}=\mathrm{Cr}, \mathrm{Co}, \mathrm{M}^{\prime}=\mathrm{Cr}, \mathrm{Mn}, \mathrm{n}=0: 3$, и $\left[\mathrm{M}_{2} \mathrm{~L}_{2} \mathrm{Co}(\mathrm{CN})_{6}\right] \cdot \mathrm{nH}_{2} \mathrm{O}$, где $\mathrm{M}=\mathrm{Ni}, \mathrm{Cu}, \mathrm{Zn}, \mathrm{L}=\mathrm{N}, \mathrm{N}$-бис(2-гидроксиэтил)этилендиамин $\left(\mathrm{C}_{2} \mathrm{H}_{5}-\mathrm{O}-\mathrm{HN}-\mathrm{CH}_{2}-\mathrm{CH}_{2}-\mathrm{NH}-\mathrm{O}-\mathrm{C}_{2} \mathrm{H}_{5}\right)$, $\mathrm{n}=3,5$, и $\left[\mathrm{Cu}(\mathrm{en})_{2}\right]\left[\mathrm{Mn}(\mathrm{ox})_{3}\right] \cdot 6 \mathrm{H}_{2} \mathrm{O}[141]$ изучено для атмосферы инертного газа. Сначала происходит отщеплением части воды, после уходит оставшаяся часть воды и начинается ступенчатое удаление амина (и NO), затем также ступенчато происходит разложение лигандов в анионе. В работе [140] показано, что если ДКС содержит Со, то при $\sim 500{ }^{\circ} \mathrm{C}$ происходит перегруппировка лигандов с образованием катиона транс-[Co(en) $\left.{ }_{2}(\mathrm{CN})_{2}\right]^{+}$. Продуктами термолиза являются цианиды ц.и., в газовой фазе определяется $(\mathrm{CN})_{2}$, температура его выделения $\sim 480-610{ }^{\circ} \mathrm{C}$, отщепление еn происходит в интервале $\sim 220-420^{\circ} \mathrm{C}$ и $\mathrm{NO}$ около $\sim 290-380^{\circ} \mathrm{C}$ [140]. Соединение $\left\{\left[\mathrm{Ni}(\mathrm{en})_{2}\right]_{3}\left[\mathrm{Fe}(\mathrm{CN})_{6}\right]_{2} \cdot 3 \mathrm{H}_{2} \mathrm{O}\right\}_{n}$ со структурой цепи типа «веревочная лестница» [142] при нагревании в атмосфере воздуха теряет воду в два этапа: в интервале $60-70{ }^{\circ} \mathrm{C}$ отщепляется одна молекула воды, а в области $100-140{ }^{\circ} \mathrm{C}$ вторая. Безводное ДКС стабильно до $200^{\circ} \mathrm{C}$. При дальнейшем повышении температуры наблюдается два сильных экзотермических эффекта с максимумами при 275 и $300{ }^{\circ} \mathrm{C}$. Конечный продукт термолиза состоит из смеси $\mathrm{NiO}+\mathrm{NiFe}_{2} \mathrm{O}_{4}$ в молярном соотношении 2:1. Авторами [143] найдено, что в случае $\mathrm{K}\left[\mathrm{CdLCo}(\mathrm{CN})_{6}\right] \cdot 1,5 \mathrm{H}_{2} \mathrm{O}$ после отщепления молекулы L происходит одновременное начало разложения $\mathrm{CN}^{-}$и возгонка калия, вероятно в виде $\mathrm{KCN}$, как и в работах $[67,68]$. Соединения обладают очень разной термической устойчивостью: разложение цианогрупп для Сu-ДКС заканчивается при $570{ }^{\circ} \mathrm{C}$ [143], а для Zn-ДКС - при $860{ }^{\circ} \mathrm{C}$ [143]. При термолизе $\left[\mathrm{Cu}(\mathrm{en})_{2}\right]\left[\mathrm{Mn}(\mathrm{ox})_{3}\right] \cdot 6 \mathrm{H}_{2} \mathrm{O}$ методом МC зарегистрированы газообразные продукты со следующими м.4.: 18 (вода), 28 (этилен или СО) и 44 (аминоэтен или $\mathrm{CO}_{2}$ ); в области $600-700{ }^{\circ} \mathrm{C}$ образуется шпинель $\mathrm{CuMn}_{2} \mathrm{O}_{4}[141]$. Разложение [Ni(L)] $\left[\mathrm{MCl}_{4}\right]$ [144], со сложным лигандом $\mathrm{L}=3,7$-бис(2аминоэтил)-1,3,5,7-тетраазобицикло(3,3,1)нонан, $\mathrm{M}=\mathrm{Co}(\mathrm{II}), \mathrm{Zn}(\mathrm{II}), \mathrm{Hg}(\mathrm{II})$ исследовано в инертной среде. Показано, что термолиз протекает в 2 этапа, сопровождающиеся экзоэффектами. В интервале $185-280{ }^{\circ} \mathrm{C}$ отщепляется хлорид-ион в виде $\mathrm{HCl}$, L остается в твердом остатке. При повышении температуры до $400{ }^{\circ} \mathrm{C}$ происходит разложение органических остатков. Конечными продуктами являются металлы.

При термолизе $\left[\mathrm{Pb}(\text { bipy })_{2}\right]_{6}\left[\mathrm{Fe}(\mathrm{CN})_{6}\right]_{4} \cdot$ bipy $14 \mathrm{H}_{2}$ $\mathrm{O}$ (bipy - $\alpha, \alpha$-бипиридил) [145] в атмосфере инертного газа и в вакууме обезвоживание происходит до $155{ }^{\circ} \mathrm{C}$, максимальная потеря массы приходится на $192{ }^{\circ} \mathrm{C}$ и связана с отщеплением трех цианогрупп. МС-метод анализа отходящих газов показал наличие следующих продуктов: радикалов $\mathrm{OH}$, $\mathrm{CN}, \mathrm{C}_{2} \mathrm{~N}_{2} \mathrm{H}$, молекул $\mathrm{H}_{2} \mathrm{O},(\mathrm{CN})_{2}, \mathrm{HCN}$.

Исследование термолиза цианомостикового координационного полимера $\left[\left(\mathrm{Me}_{3} \mathrm{Sn}\right){ }_{n} \mathrm{M}(\mathrm{CN})_{6}\right]$, где $\left(\mathrm{Me}=\mathrm{CH}_{3} ; n=3,4 ; \mathrm{M}=\mathrm{Fe}, \mathrm{Co}, \mathrm{Ru}\right)$ [146] проведено в воздушной, инертной и восстановительной атмосферах. Определены следующие конечные продукты: на воздухе $\mathrm{Co}_{2} \mathrm{SnO}_{4}$ и смеси $\alpha-\mathrm{Fe}_{2} \mathrm{O}_{3}+\mathrm{SnO}_{2}$ и $\mathrm{RuO}_{2}+\mathrm{SnO}_{2}$; в $\mathrm{Ar}$ и $\mathrm{H}_{2}$ получены интерметаллиды $\mathrm{FeSn}_{2}, \mathrm{Fe}_{3} \mathrm{SnC} \mathrm{CoSn}_{2}$ и $\mathrm{Ru}_{3} \mathrm{Sn}_{4}$. При температурах $<250{ }^{\circ} \mathrm{C}$ происходит удаление $\mathrm{Me}_{3} \mathrm{SnCN}$ и $(\mathrm{CN})_{2}$. В случае ДКС $\mathrm{M}\left(\mathrm{NH}_{3}\right)_{2}\left[\mathrm{Ag}(\mathrm{CN})_{2}\right]_{2}(\mathrm{M}=\mathrm{Ni}, \mathrm{Cu}, \mathrm{Cd})$ [132] при термолизе на воздухе наблюдается эндоэффект $\sim$ до $190-240{ }^{\circ} \mathrm{C}$, в этом интервале отщепляется весь аммиак и образуется смесь цианидов $\mathrm{Ni}$ и $\mathrm{Ag}$ или $\mathrm{M}\left[\mathrm{Ag}(\mathrm{CN})_{2}\right]_{2}$, где $\mathrm{M}=\mathrm{Cu}, \mathrm{Cd}$. Затем происходит выделение дициана, $\mathrm{M}\left[\mathrm{Ag}(\mathrm{CN})_{2}\right]_{2}$ распадается на смесь цианидов; и конечными продуктами термолиза при $460{ }^{\circ} \mathrm{C}$ являются оксиды металлов и $\mathrm{Ag}^{0}$.

В работах $[147,148]$ подробно изучен термолиз ДКС $\left[\mathrm{Co}(\mathrm{en})_{3}\right]\left[\mathrm{Fe}(\mathrm{CN})_{6}\right] \cdot 2 \mathrm{H}_{2} \mathrm{O}$ в атмосфере воздуха, схема разложения представлена на рисунке 6 . 
Полугидрат $\left[\mathrm{Co}(\mathrm{en})_{3}\right]\left[\mathrm{Fe}(\mathrm{CN})_{6}\right] \cdot 0,5 \mathrm{H}_{2} \mathrm{O}$ (I) образуется в интервале температур $50-80{ }^{\circ} \mathrm{C}$ и устойчив до $187{ }^{\circ} \mathrm{C}$. При нагревании до $240{ }^{\circ} \mathrm{C}$ (I) превращается в $\left[\mathrm{Fe}^{\mathrm{II}}(\mathrm{en})_{2}(\mu-\mathrm{NC}) \mathrm{Co}^{\mathrm{III}}(\mathrm{CN})_{4}\right]$ (II). По мессбауэровскому спектру установлена степень окисления железа и КЧ $=5$. Но есть признаки и присутствия $\mathrm{Fe}(\mathrm{III})$ с КЧ $=4$. Восстановление железа(III) происходит за счет окисления цианогрупп до дициана. Дициан реагирует с двумя молекулами этилендиамина с образованием бициклической молекулы бис-2-имидазолила. Сходный процесс описан в работе [35] и наблюдается для этилендиаминовых соединений около $200{ }^{\circ} \mathrm{C}$. $\left[\mathrm{Fe}^{\mathrm{II}}(\mathrm{en})_{2}(\mu-\mathrm{NC}) \mathrm{Co}^{\mathrm{III}}(\mathrm{CN})_{4}\right]$ частично превращается в $\left[\mathrm{Fe}^{\mathrm{III}}\left(\mathrm{H}_{2} \mathrm{NCH}_{2} \mathrm{CH}_{3}\right)_{2}(\mu-\mathrm{NC})_{2} \mathrm{Co}^{\mathrm{II}}(\mathrm{CN})_{3}\right]$ (III), так что содержание $\mathrm{Fe}(\mathrm{II})$ составляет $1 / 3$ от общего железа. III образуется при нагревании исходного ДКС до $300{ }^{\circ} \mathrm{C}$. Его образование происходит с уча- стием атмосферного кислорода и выделением оксидов азота. Эта стадия связана с широким эндоэффектом с минимумом при $214{ }^{\circ} \mathrm{C}$. ИК-спектры интермедиатов II и III подтверждают предложенный механизм разложения. Образование цианомостика связано со сдвигом $v(\mathrm{CN})$ с 2113 до $2132 \mathrm{~cm}^{-1}$ в интервале температур $150 \rightarrow 230 \rightarrow 265^{\circ} \mathrm{C}$ и относится к $v\left(\mathrm{Fe}^{\mathrm{II}}-\mathrm{CN}-\mathrm{Co}^{\text {III }}\right)$. Интенсивность этой полосы понижается с повышением температуры, указывая на отсутствие этого типа координации свыше $265^{\circ} \mathrm{C}$. С другой стороны, сдвиг пика $2104 \rightarrow 2062 \rightarrow 2066 \mathrm{~cm}^{-1}$ в этой же области температур соответствует $v\left(\mathrm{Fe}^{\mathrm{III}}-\mathrm{CN}-\mathrm{Co}^{\mathrm{II}}\right)$. Эти наблюдения подтверждают механизм разложения с накоплением III при повышении температуры и указывают на наличие мостика $\mathrm{Fe}^{\mathrm{III}}-\mathrm{CN}-\mathrm{Co}^{\mathrm{II}}$ в III. При нагревании до $350{ }^{\circ} \mathrm{C}$ образуется интермедиат IV $\mathrm{Fe}^{\mathrm{III}}\left[\mathrm{Co}^{\mathrm{II}}(\mathrm{CN})_{5}\right]\left(\mathrm{C}_{5} \mathrm{~N}_{5} \mathrm{CoFe}\right)$. Эта стадия реакции

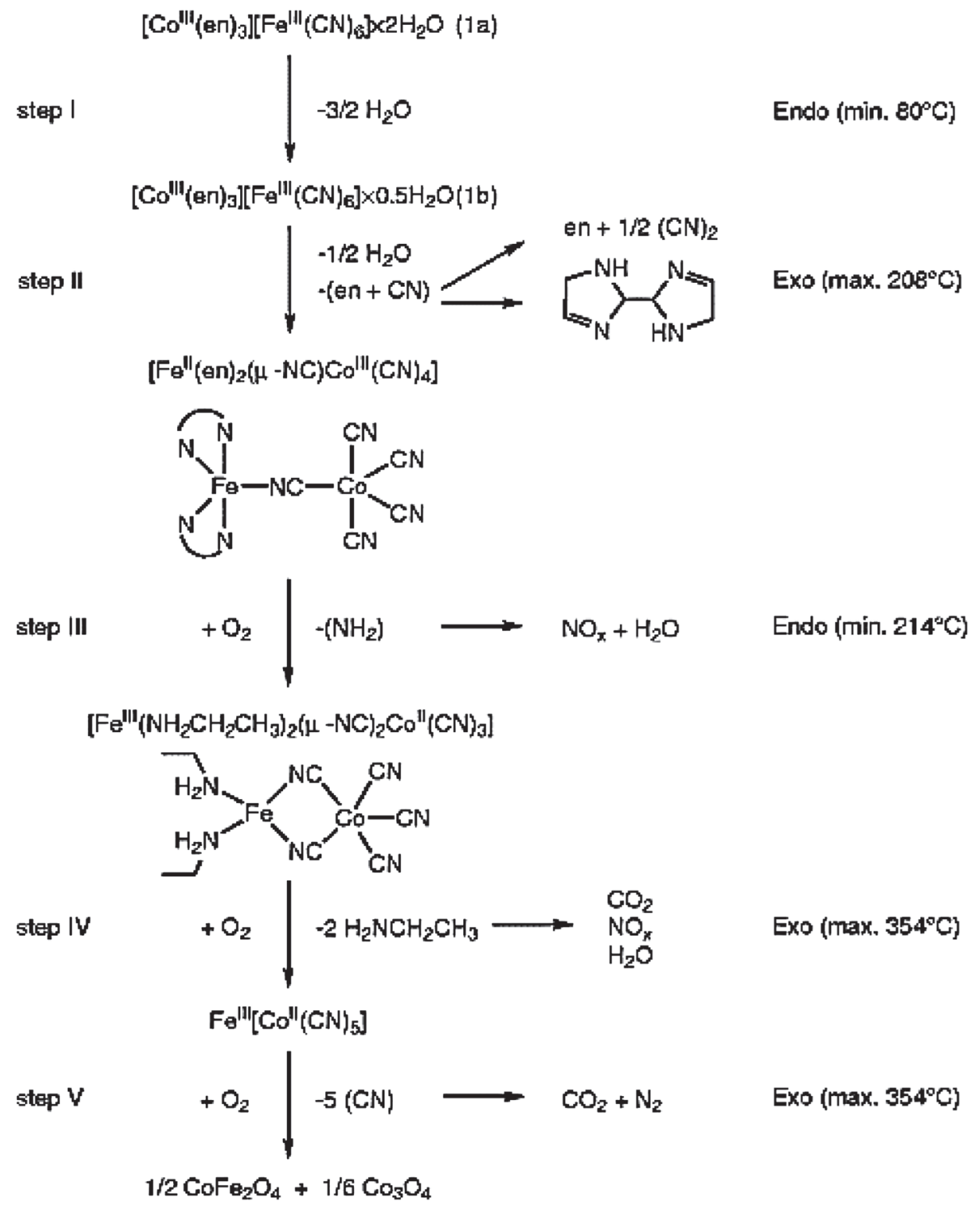

Рис. 6. Схема разложения $\left[\mathrm{Co}(\mathrm{en})_{3}\right]\left[\mathrm{Fe}(\mathrm{CN})_{6}\right] \cdot 2 \mathrm{H}_{2} \mathrm{O}$ в атмосфере воздуха [147] 
отражается на кривой ДТА как плечо в области 335-354 ${ }^{\circ} \mathrm{C}$. В мессбауэровском спектре образца IV не обнаруживается присутствия $\mathrm{Fe}(\mathrm{II})$.

Свыше $350{ }^{\circ} \mathrm{C}$ отмечается выделение $\mathrm{CO}_{2}$. Конечный продукт термолиза $\mathbf{V}$ был получен при $420{ }^{\circ} \mathrm{C}$. Суммарная потеря массы составляет $61,7 \%$ (расчетная 62,1\%). Это соответствует удалению воды, всех молекул еn и всех циано-групп и/или окислению металлов с образованием шпинельной фазы брутто состава $\mathrm{Co}_{1,5} \mathrm{Fe}_{1,5} \mathrm{O}_{4}$. Колебания, соответствующие цианогруппе, в ИК-спектре $\mathbf{V}$ отсутствуют. Мессбауэровский спектр исключает наличие $\mathrm{Fe}(\mathrm{II})$ в фазе оксидов железа. Данные РДА позволили установить, что $\mathbf{V}$ это смесь $\mathrm{CoFe}_{2} \mathrm{O}_{4}$ и $\mathrm{Co}_{3} \mathrm{O}_{4}$.

$\mathrm{B}$ работе [6] указано, что нагревании $\left[\mathrm{Co}(\mathrm{en})_{3}\right]_{4}\left[\mathrm{Fe}(\mathrm{CN})_{6}\right]_{3} \cdot 21,6 \mathrm{H}_{2} \mathrm{O}$ в атмосфере аргона при $97^{\circ} \mathrm{C}$ наблюдается эндотермический эффект, авторы предполагают, что происходит удаление $\mathrm{NH}_{3}$ и воды. Процессы, происходящие при дальнейшем нагревании, не исследованы.

На рис. 7 представлены кривые ТГ ряда ДКС в воздушной среде. Видно, что потеря внешнесферной воды происходит в области от 50 до $200^{\circ} \mathrm{C}$, и обезвоженные ДКС устойчивы не более чем до $200{ }^{\circ} \mathrm{C}$. Термическое разложение продуктов распада ДКС происходит от $300{ }^{\circ} \mathrm{C}$ до $460{ }^{\circ} \mathrm{C}$.

Единый цикл составляют работы $[110,166]$ авторов настоящего обзора, посвященные систематическому сравнительному исследованию термолиза ДКС 3d-металлов в интервале температур от комнатной до $1000{ }^{\circ} \mathrm{C}$ в окислительной, инертной и восстановительной атмосферах, где были изучены следующие соединения: $\left[\mathrm{Co}\left(\mathrm{NH}_{3}\right)_{6}\right]\left[\mathrm{Fe}(\mathrm{CN})_{6}\right]$ (1) $[13,81,110,149,150$, $158,164],\left[\mathrm{Co}\left(\mathrm{NH}_{3}\right)_{6}\right]_{4}\left[\mathrm{Fe}(\mathrm{CN})_{6}\right]_{3} \cdot 13 \mathrm{H}_{2} \mathrm{O}$ (2) $[13,81$,

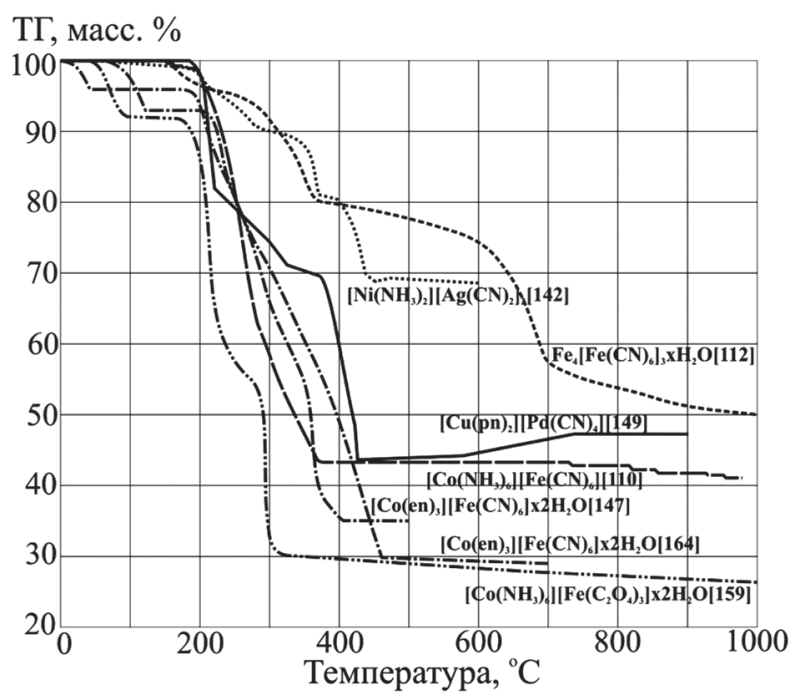

Рис. 7. Кривые термического анализа (ТГ) ДКС на воздухе
110, 150], $\left[\mathrm{Co}\left(\mathrm{NH}_{3}\right)_{6}\right]\left[\mathrm{Cr}(\mathrm{NCS})_{6}\right] \cdot 2 \mathrm{H}_{2} \mathrm{O}(3)[110,154$, 158], $\left[\mathrm{Co}\left(\mathrm{NH}_{3}\right)_{6}\right]\left[\mathrm{Cr}\left(\mathrm{C}_{2} \mathrm{O}_{4}\right)_{3}\right] \cdot 4 \mathrm{H}_{2} \mathrm{O}$ (4) $[110,156$, 158], $\left[\mathrm{Co}\left(\mathrm{NH}_{3}\right)_{6}\right]\left[\mathrm{Cu}\left(\mathrm{C}_{7} \mathrm{H}_{4} \mathrm{O}_{3}\right)_{2}\right] \mathrm{Cl} \cdot 2 \mathrm{H}_{2} \mathrm{O}$ (5) $[110,152$, 153,], $\quad\left[\mathrm{Ni}\left(\mathrm{NH}_{3}\right)_{6}\right]_{3}\left[\mathrm{Fe}(\mathrm{CN})_{6}\right]_{2}(\mathbf{6}) \quad[15,81, \quad 110,151$, $155,164], \quad\left[\mathrm{Ni}\left(\mathrm{NH}_{3}\right)_{6}\right]_{3}\left[\mathrm{Cr}(\mathrm{NCS})_{6}\right]_{2}$ (7) $[110,155$, 158], $\left[\mathrm{Ni}_{2}(\mathrm{en})_{3}\left(\mathrm{H}_{2} \mathrm{O}\right)_{6}\right]\left[\mathrm{MnFe}(\mathrm{CN})_{6}\right]_{2}(\mathbf{8}) \quad[110,165]$, $\left[\mathrm{Cu}(\mathrm{en})\left(\mathrm{H}_{2} \mathrm{O}\right)_{2}\right]\left[\mathrm{MnFe}(\mathrm{CN})_{6}\right] \cdot \mathrm{H}_{2} \mathrm{O} \quad$ (9) $[110, \quad 165]$, $\left[\mathrm{Co}\left(\mathrm{NH}_{3}\right)_{6}\right]_{2}\left[\mathrm{Cu}\left(\mathrm{C}_{2} \mathrm{O}_{4}\right)_{2}\right]_{3}(\mathbf{1 0})[110,157],\left[\mathrm{Co}\left(\mathrm{NH}_{3}\right)_{6}\right]$ $\left[\mathrm{Fe}\left(\mathrm{C}_{2} \mathrm{O}_{4}\right)_{3}\right] \cdot 2 \mathrm{H}_{2} \mathrm{O} \quad$ (11) $\quad[159, \quad 160], \quad\left[\mathrm{Co}(\mathrm{en})_{3}\right]$ $\left[\mathrm{Fe}\left(\mathrm{C}_{2} \mathrm{O}_{4}\right)_{3}\right] \cdot 4 \mathrm{H}_{2} \mathrm{O}(\mathbf{1 2})[159],\left[\mathrm{Co}(\mathrm{en})_{3}\right]\left[\mathrm{Cr}\left(\mathrm{C}_{2} \mathrm{O}_{4}\right)_{3}\right] \cdot 4 \mathrm{H}_{2} \mathrm{O}$ (13) $[159],\left[\mathrm{Co}(\mathrm{en})_{3}\right]\left[\mathrm{Fe}(\mathrm{CN})_{6}\right] \cdot 2 \mathrm{H}_{2} \mathrm{O}$ (14) $[14,166]$, $\left[\mathrm{Co}(\mathrm{en})_{3}\right]_{4}\left[\mathrm{Fe}(\mathrm{CN})_{6}\right]_{3} \cdot 15 \mathrm{H}_{2} \mathrm{O}(\mathbf{1 5})[14,166],\left[\mathrm{Ni}_{\mathrm{a}}(\mathrm{Pn})_{\mathrm{b}}\right]$ ${ }_{\mathrm{x}}\left[\mathrm{Fe}(\mathrm{CN})_{6}\right]_{\mathrm{y}}(\mathbf{1 6}-\mathbf{1 9})[64,166],\left[\mathrm{Cr}(\mathrm{ur})_{6}\right]\left[\mathrm{Fe}(\mathrm{CN})_{6}\right] \cdot 3 \mathrm{H}_{2} \mathrm{O}$ (20) $[161,166,167],\left[\mathrm{Cr}(\mathrm{ur})_{6}\right]_{4}\left[\mathrm{Fe}(\mathrm{CN})_{6}\right]_{3} \cdot 18 \mathrm{H}_{2} \mathrm{O}$ (21) $[161,166],\left[\mathrm{Cr}(\mathrm{ur})_{6}\right]\left[\mathrm{Co}(\mathrm{CN})_{6}\right] \cdot 3 \mathrm{H}_{2} \mathrm{O}$ (22) $[162,166$, 167], $\left[\mathrm{Cr}(\mathrm{ur})_{6}\right]\left[\mathrm{Fe}\left(\mathrm{C}_{2} \mathrm{O}_{4}\right)_{3}\right] \cdot 3 \mathrm{H}_{2} \mathrm{O}$ (23) $[161,166,167]$, $\left[\mathrm{Cr}(\mathrm{ur})_{6}\right]\left[\mathrm{Co}\left(\mathrm{C}_{2} \mathrm{O}_{4}\right)_{3}\right] \cdot 3 \mathrm{H}_{2} \mathrm{O}(\mathbf{2 4})[161,166,167],\left[\mathrm{Cr}(\mathrm{ur})_{6}\right]$ $\left[\mathrm{Co}\left(\mathrm{NO}_{2}\right)_{6}\right]$ (25) $[161,166],[\mathrm{Cupn}]_{3}\left[\mathrm{Fe}(\mathrm{CN})_{6}\right]_{2} \cdot 8 \mathrm{H}_{2} \mathrm{O}$ (26) $[163,166], \quad\left[\mathrm{Cu}(\mathrm{pn})_{2}\right]_{3}\left[\mathrm{Fe}(\mathrm{CN})_{6}\right]_{2} \cdot 5 \mathrm{H}_{2} \mathrm{O} \cdot \mathrm{KCl}$ (27) $[163,166], \quad[\mathrm{Cupn}]_{2}\left[\mathrm{Fe}(\mathrm{CN})_{6}\right] \cdot 3 \mathrm{H}_{2} \mathrm{O}(\mathbf{2 8}) \quad[163$, 166], $\left[\mathrm{Rh}(\mathrm{en})_{3}\right]\left[\mathrm{Fe}(\mathrm{CN})_{6}\right] \cdot 2 \mathrm{H}_{2} \mathrm{O}(\mathbf{2 9})[168],\left[\mathrm{Rh}(\mathrm{en})_{3}\right]$ $\left[\mathrm{Co}(\mathrm{CN})_{6}\right] \cdot 2 \mathrm{H}_{2} \mathrm{O}(\mathbf{3 0})$ [168]. Исследованию подвергались природа твердых остатков от прокаливания и газообразных продуктов термолиза (ГПТР) ДКС.

Рассмотрение материалов указанного цикла работ по термолизу ДКС позволяет прийти к выводу, что большое влияние на ход процесса оказывают, во-первых, природа ц.и. как катионной, так и анионной части ДКС. Во-вторых, природа газовой атмосферы, в которой проводится термолиз, так же сильно влияет на ход процесса, как и в случае анионных КС. При наличии относительно простых, нейтральных лигандов в катионной части ДКС $\left(\mathrm{NH}_{3}\right.$, en, $\left.\mathrm{H}_{2} \mathrm{O}\right)$ отщепление этих лигандов, как и в случае монокомплексов, протекает ступенчато в области низких температур $\left(\leq 200{ }^{\circ} \mathrm{C}\right)$. Однако, если лиганды в катионе имеют очень сложный состав и большую молекулярную массу [146], то простые лиганды из аниона $\left(\mathrm{Cl}^{-}\right.$в работе [146]) могут удаляться прежде, чем фрагменты нейтрального лиганда.

Рассмотрим для ДКС 1-30 общие черты в поведении при термическом разложении на воздухе (рис. 7). Все они менее устойчивы к нагреванию на воздухе, чем исходные монокомплексы и допускают нагревание на воздухе не более чем до $200{ }^{\circ} \mathrm{C}$. При термолизе на воздухе твердыми продуктами являлись простые или смешанные оксиды ц.и. При наличии в комплексе серусодержащего лиганда $\mathrm{SCN}^{-}$образовывались также сульфиды и сульфаты ц.и. Так как большая часть изученных ДКС содержит в своем составе кристаллизационную воду, а их катионы - координированные аммиак и амины, то, как правило, на кривых ДТА наблюдался сначала эндоэффект в области около 
$200{ }^{\circ} \mathrm{C}$, который и связан с отщеплением аммиака и воды (если она есть). Дальнейшее поведение ДКС при термолизе на воздухе зависело от того, какие лиганды присутствуют в анионе. Если это оксалатионы, то разложение ДКС с отщеплением $\mathrm{CO}_{2}$ шло практически в одну стадию. В случае тиоцианатионов процесс термолиза усложнялся, шло последовательное выгорание серы одновременно с выгоранием углерода и азота. Хотя в окислительной атмосфере твердыми продуктами термолиза являются оксиды металлов-комплексообразователей, за исключением $\mathrm{Au}$ и $\mathrm{Pt}$, для соединений 16-19 мы наблюдали и $\mathrm{Ni}^{0}$, поскольку tn обладает сильными восстановительными свойствами.

В области температур 200-350 ${ }^{\circ} \mathrm{C}$ твердые остатки рентгеноаморфны, кроме меди. Эти остатки уже не являются исходными ДКС, а представляют собой осколки структур. От $350{ }^{\circ} \mathrm{C}$ у всех ДКС начинается быстрая плавная потеря массы (до $50 \%$ исходной массы) с выделением различных газообразных продуктов. Во-первых, выделяется некоторая часть координированных в составе катиона лигандов (ur, en, tn); во-вторых, продукты термической деструкции этих лигандов: HNCO (из ur) и $\mathrm{NH}_{3}$; при этом должны быть также углеводородные остатки en и tn, (например, был зарегистрирован $\mathrm{C}_{3} \mathrm{H}_{5} \mathrm{HN}_{2}$ ); в-третьих, параллельно с разрушением катиона идет и разрушение анионов с выделением $\mathrm{HCN}$ из цианокомплексов. При нагревании ДКС на воздухе выделение $\mathrm{HCN}$ происходит в 1 стадию в области $\sim 180-350{ }^{\circ} \mathrm{C}$. Основная масса $\mathrm{HCN}$ выделяется до $\sim 250{ }^{\circ} \mathrm{C}$ и некоторое количество выделяется дополнительно в виде шлейфа. Потеря массы прекращается до $550-600{ }^{\circ} \mathrm{C}$. Потери массы в виде $\mathrm{HCN}$ в \% от содержания цианогрупп, например: $\left.[\mathrm{Cu}(\mathrm{tn})]_{3}\left[\mathrm{Fe}(\mathrm{CN})_{6}\right]_{2} \cdot 8 \mathrm{H}_{2} \mathrm{O}, \quad\left[\mathrm{Ni}(\mathrm{tn})_{2}\right]_{3}\left[\mathrm{Fe}(\mathrm{CN})_{6}\right]_{2} \cdot 6 \mathrm{H}_{2} \mathrm{O}\right)$ и ДКС $\left.\left[\mathrm{Co}(\mathrm{en})_{3}\right]\left[\mathrm{Fe}(\mathrm{CN})_{6}\right] \cdot 2 \mathrm{H}_{2} \mathrm{O}\right)-20 \%$ при $300{ }^{\circ} \mathrm{C}$; для ДКС $\left[\mathrm{Co}(\mathrm{en})_{3}\right]\left[\mathrm{Fe}(\mathrm{CN})_{6}\right] \cdot 2 \mathrm{H}_{2} \mathrm{O}-25 \%$ при $550{ }^{\circ} \mathrm{C}$; $33 \%$ при $550{ }^{\circ} \mathrm{C}$ для $\left[\mathrm{Ni}(\mathrm{tn})_{2}\right]_{3}\left[\mathrm{Fe}(\mathrm{CN})_{6}\right]_{2} \cdot 6 \mathrm{H}_{2} \mathrm{O}$, таким образом 1,2-2 моль $\mathrm{HCN} /$ ион $\left[\mathrm{Fe}(\mathrm{CN})_{6}\right]^{3-}$.

Таким образом, разложение цианокомплексов на воздухе сводится к отщеплению части лигандов из катиона, выделению части $\mathrm{CN}^{-}$-групп из аниона и окислению всей оставшейся части до $\mathrm{CO}, \mathrm{CO}_{2}$, $\mathrm{N}_{2} \mathrm{O}, \mathrm{N}_{2}$ и оксидов ц.и. Молекулярный азот не обнаруживается использованными методами, но составление материального баланса по продуктам показывает, что он должен быть в числе продуктов.

Наиболее сложным образом происходит термическое разложение ДКС в инертной атмосфере, и особенно ДКС, содержащих в качестве анионной части цианометаллаты (рис. 8). В качестве твердых продуктов термолиза в инертной атмосфере образуются интерметаллиды, твердые растворы и бинарные смеси металлов-комплексообразовате- лей (за исключением хрома). Если лиганды содержат кислород (мочевина, $\mathrm{C}_{2} \mathrm{O}_{2}{ }^{2-}, \mathrm{NO}_{2}{ }^{-}$), то в твердом остатке обязательно присутствует примесь оксидов ц.и. При термолизе в атмосфере аргона ДКС, содержащих амины и цианогруппы, в интервале температур от $\sim 300$ до $600{ }^{\circ} \mathrm{C}$ наблюдается большая потеря массы, ИКС ГПТР в этой области также регистрирует сильное одновременное выделения $\mathrm{NH}_{3}$ и $\mathrm{HCN}$. В интервале $600-720{ }^{\circ} \mathrm{C}$ наблюдается потеря 6-10 \% массы, которую мы относим к выделению элементарного азота из оставшихся цианогрупп, так как при проведении ИКСанализа ГПТР не было зафиксировано какого-либо сигнала, соответствующего этой потере массы в указанной области температур. Процесс потери массы в атмосфере аргона происходит вплоть до $1000{ }^{\circ} \mathrm{C}$, и возможно, даже при этом не заканчивается. Остатки от прокаливания во всех интервалах температур показывают содержание углерода, значительно превышающее таковое при соответствующих температурах в атмосферах воздуха и водорода. Так, минимальное остаточное содержание углерода среди соединений с цианогруппами равно 7,1\% - при $700{ }^{\circ} \mathrm{C}$ для ДКС $\left[\mathrm{Ni}(\mathrm{tn})_{2}\right]_{3}\left[\mathrm{Fe}(\mathrm{CN})_{6}\right]_{2} \cdot 6 \mathrm{H}_{2} \mathrm{O}$ - также $7,1 \%$ остается при $800{ }^{\circ} \mathrm{C}$ для ДКС $[\mathrm{Cu}(\mathrm{tn})]_{3}\left[\mathrm{Fe}(\mathrm{CN})_{6}\right]_{2} \cdot 8 \mathrm{H}_{2} \mathrm{O}$, а максимальное $-45,5 \%$, при термолизе при $900{ }^{\circ} \mathrm{C} \mathrm{ДКС}$ $\left[\mathrm{Co}(\mathrm{en})_{3}\right]\left[\mathrm{Fe}(\mathrm{CN})_{6}\right] \cdot 2 \mathrm{H}_{2} \mathrm{O}$. Поскольку ИКС-анализ твердых остатков и ГПТР показывают, что в области температур около $1000{ }^{\circ} \mathrm{C}$ лиганды катиона (амины) отсутствуют, этот остаточный углерод, очевидно, является продуктом разложения цианогрупп. Выделение каждого газообразного продукта (рис. 8) в инертной атмосфере происходит в несколько четко выраженных стадий, чего

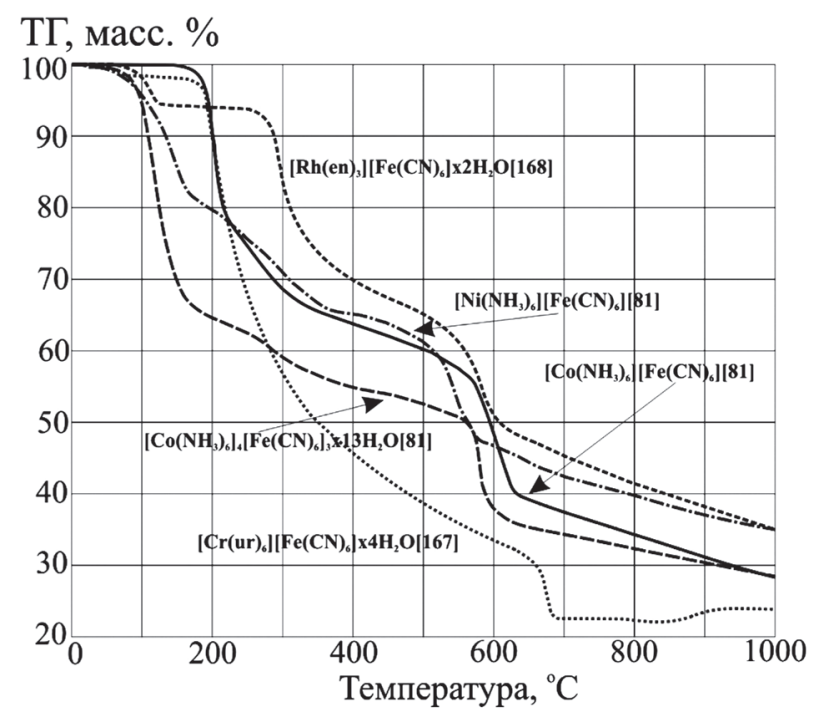

Рис. 8. Кривые термического анализа (ТГ) ДКС в аргоне 
не наблюдалось в атмосфере воздуха, пиков выделения ГПТР больше, они выше и шире по температурному интервалу. Так, в атмосфере воздуха газообразные продукты выделяются в 1-2 (ДКС [Co(en) $\left.)_{3}\right]$ $\left.\left[\mathrm{Fe}(\mathrm{CN})_{6}\right] \cdot 2 \mathrm{H}_{2} \mathrm{O}, \quad\left[\mathrm{Ni}_{5}(\mathrm{tn})_{9}\right]\left[\mathrm{Fe}(\mathrm{CN})_{6}\right]_{3} \cdot 9 \mathrm{H}_{2} \mathrm{O}\right)$ или $2-3$ стадии (ДКС $\left.[\mathrm{Cu}(\mathrm{tn})]_{3}\left[\mathrm{Fe}(\mathrm{CN})_{6}\right]_{2} \cdot 8 \mathrm{H}_{2} \mathrm{O}\right)$, а в $\mathrm{N}_{2}$ наблюдается 3 или больше стадий для всех ДКС.

Провести термический анализ в атмосфере, содержащей водород (гелий +8 об. \% $\mathrm{H}_{2}$ ) удалось провести только для соединений $1,4,11,17,26$. Кривые термического анализа в этом случае очень похожи на соответствующие кривые для инертных атмосфер (аргона, азота), хотя процесс заканчивается при несколько меньшей температуре, чем в аргоне, образованием металлов ц.и. Установлено, что качественно ГПТР в атмосфере $\mathrm{H}_{2}$ совпадают с ГПТР в воздухе и инертной среде, но повышенный выход $\mathrm{NH}_{3}$ и пониженный выход $\mathrm{CO}_{2}$ и/или $\mathrm{HCN}$ говорят в пользу частичного гидрирования лигандов.

Для восстановительной среды рассматривались продукты разложения ДКС преимущественно в статических экспериментах, в чистом водороде. Твердыми продуктами термолиза ДКС являлись металлические фазы (интерметаллиды или твердые растворы), сульфиды или оксиды. В случае ДКС 1 и 2 конечным продуктом является твердый раствор $\mathrm{CoFe}$, в случае $\mathbf{6}-\mathrm{NiFe}$. Для соединений 5 и 10 получены смеси $\mathrm{Co}+\mathrm{Cu}$, для 4 $\mathrm{Co}+\mathrm{Cr}_{2} \mathrm{O}_{3}$. Для тиоцианатных ДКС 3 и 7 конечными продуктами также являлись смеси $\mathrm{Co}+\mathrm{CoCr}_{2} \mathrm{~S}_{4}$ и $\mathrm{Ni}_{3} \mathrm{~S}_{2}+\mathrm{NiCr}_{2} \mathrm{~S}_{4}$, соответственно. Марганец был найден в составе твердых продуктов только в оксидной форме, но, вероятно, он выделяется в виде высокодисперсного металла, который быстро окисляется на воздухе.

Были изучены также газообразные продукты термолиза ДКС 1-10 в атмосфере $\mathrm{H}_{2}$. Координированные лиганды аниона (CN-, $\left.\mathrm{C}_{2} \mathrm{O}_{4}^{2-}, \mathrm{CNS}^{-}\right)$ подвергаются гидрированию и восстанавливаются до метана и некоторого количества низших углеводородов (УВ). При гидрировании $\mathrm{CNS}^{-}$получается $\mathrm{NH}_{3}$, УВ и $\mathrm{H}_{2} \mathrm{~S}, \mathrm{a} \mathrm{C}_{2} \mathrm{O}_{4}{ }^{2-}-$ УВ и $\mathrm{CO}_{2}[158]$. Например: при прокаливании $\left[\mathrm{Co}\left(\mathrm{NH}_{3}\right)_{6}\right]\left[\mathrm{Fe}(\mathrm{CN})_{6}\right]$ при $350{ }^{\circ} \mathrm{C}$ получено соотношение продуктов гидрирования метан : непредельные УВ $=1: 0,88$; в случае $\left[\mathrm{Co}\left(\mathrm{NH}_{3}\right)_{6}\right]_{4}\left[\mathrm{Fe}(\mathrm{CN})_{6}\right]_{3} \cdot 13 \mathrm{H}_{2} \mathrm{O}$ при $500{ }^{\circ} \mathrm{C}$ и $\left[\mathrm{Ni}\left(\mathrm{NH}_{3}\right)_{6}\right]_{3}\left[\mathrm{Cr}(\mathrm{NCS})_{6}\right]_{2}$ при $350{ }^{\circ} \mathrm{C}$ получено соотношение метан : непредельные УВ $\approx 1: 0,55$. В большинстве случаев суммарное содержание углеводородов, отличных от метана, не превышает $15 \%$ от содержания последнего. Повышение температуры термолиза способствует повышению относительного выхода метана [158].

Мы пришли к выводу, что при термолизе в атмосфере водорода ДКС, содержащих $\mathrm{Ni}$ и $\mathrm{Fe}$ или $\mathrm{Co}$ и $\mathrm{Fe}$, образуются однофазные системы - твердые растворы $\mathrm{NiFe}$ и $\mathrm{CoFe}$, или интерметаллиды $\mathrm{Co}_{\mathrm{x}} \mathrm{Fe}_{1-\mathrm{x}}$. При термолизе соединений, содержащих $\mathrm{Co}$ и $\mathrm{Cu}$, получены двухфазные порошки $\mathrm{Co}+\mathrm{Cu}$. Термолиз ДКС, содержащих $\mathrm{Cr}$, не приводит к образованию металлического хрома. ДКС с серосодержащими лигандами не образуют при термолизе чистых металлических фаз. При термолизе других ДКС в атмосфере водорода происходит гидрирование лигандов как и для 1-10. При термолизе углеродсодержащих лигандов образуются углеводороды, преобладающим среди которых является метан, азот переходит в аммиак, сера - в сероводород. Координированный аммиак отщепляется в неизмененном виде.

Если же в состав ДКС входят вместо цианогрупп оксалато- или нитрогруппы, ход термолиза существенно отличается от термолиза цианидных ДКС, что видно на примере соединений $3,4,5,7,10$ 13, 23-25 в атмосфере воздуха, аргона, водорода. Координированные оксалат-ионы в инертной среде отщепляются в виде $\mathrm{CO}_{2}$ (максимально до $80 \%$ ) и $\mathrm{CO}$ (до $41 \%$ ), причем выход $\mathrm{CO}_{2}$ возрастает с повышением температуры термолиза. Напоминаем, что если в состав соединений входят цианогруппы, то в инертной среде они выделяются в виде HCN (не более $1 / 3$ всех цианогрупп) и $\mathrm{N}_{2}$, который выделяется в области температур около $600{ }^{\circ} \mathrm{C}$. Начальные стадии термолиза и этих ДКС протекают отчасти с отщеплением лигандов катиона. Исключением является соединение $\left[\mathrm{Cr}(\mathrm{ur})_{6}\right]\left[\mathrm{Co}\left(\mathrm{NO}_{2}\right)_{6}\right]$, при термолизе которого вне зависимости от газовой среды, координированная нитрогруппа реагирует с координированной мочевиной с образованием аммиака, азота и углекислого газа [161]. В остатках от прокаливания всех ДКС в инертной атмосфере обнаружен аморфный углерод, его содержание доходит до $58 \%$ от исходного содержания С в случае комплекса $\left[\mathrm{Ni}\left(\mathrm{NH}_{3}\right)_{6}\right]_{3}\left[\mathrm{Fe}(\mathrm{CN})_{6}\right]_{2}[15]$.

В работах по синтезу и исследованию ДКС для новых соединений обычно проводят рентгеноструктурные исследования. Поскольку кристаллическая структура является одним из основных факторов, влияющих на термическое разложение соединений, особенно ДКС, рассмотрим данные по известным кристаллическим структурам ДКС 3d-металлов.

В работе [169] описано получение и некоторые свойства солей с катионом $\left[\mathrm{Cr}(\mathrm{ur})_{6}\right]^{3+}$, в том числе 20-25. Описана окраска, количество молекул кристаллизационной воды, устойчивость на воздухе и при облучении. Если в 1889 г. для 20 указывали 4 молекулы внешнесферной воды, а для 21 - 17, то авторы [169] получали 21 с различным количеством молекулы воды. 22 получен в виде матово-зеленого 
осадка, причем 22 отмечен как гораздо более устойчивый, чем 20. Для 20 и 22 определены формулы с 4 молекулами воды, для 24 - с 0,5 молекулы.

Никаких упоминаний о кристаллической структуре соединений 20-25 нам не удалось найти, однако есть основания предполагать, что их кристаллическая структура аналогична структуpe $\left[\mathrm{Co}\left(\mathrm{NH}_{3}\right)_{6}\right]\left[\mathrm{Fe}(\mathrm{CN})_{6}\right]$ и других подобных соединений, то есть, предполагать островную структуру со слабыми водородными связями.

Структура 14 описана в работах [6, 147, 148]. ДКС кристаллизуется в моноклинной системе, с мало искаженной октаэдрической конфигурацией катионов и анионов. Кристаллическая ячейка обладает островной структурой, то есть состоит из катиона $\left[\mathrm{Co}(\mathrm{en})_{3}\right]^{3+}$ и двух обобщенных, кристаллографически независимых комплексных анионов $\left[\mathrm{Fe}(\mathrm{CN})_{6}\right]^{3-}$ с ионами железа (III), занимающими специальные позиции (центры инверсии). Структура обладает центром инверсии, присутствуют обе конформации катиона $\left[\mathrm{Co}(\mathrm{en})_{3}\right]^{3+}-\mathrm{lel}_{3}$ и $o b_{3}[6]$. Молекулы кристаллизационной воды не играют большой роли в его структуре, образуя очень слабые водородные связи, а их удаление путем осторожного высушивания при $80^{\circ} \mathrm{C}$ не приводит к изменению типа кристаллической решетки, только к небольшому уменьшению значений параметров ячейки[6]. Из числа ДКС, содержащих в катионе аммиак или этилендиамин, а в анионе оксалат-ионы, только для $\left[\mathrm{Co}(\mathrm{en})_{3}\right]\left[\mathrm{Cr}\left(\mathrm{C}_{2} \mathrm{O}_{4}\right)_{3}\right] \cdot 4 \mathrm{H}_{2} \mathrm{O}$ [170] удалось найти описание кристаллической структуры комплекса, которая включает длинные цепи чередующихся катионов и анионов, ориентированные вдоль кристаллографической оси с. Ионы связаны многократно повторяющимися водородными связями $\mathrm{N}-\mathrm{H} \cdots \mathrm{O}$, группы $\mathrm{N}-\mathrm{H}$ связаны с двумя различными оксалатными хелатными кольцами. Сильные водородные связи имеют место между соседними цепями. Есть основание думать, что аналогичными структурами обладают и остальные три изучаемые ДКС. О наличии сильных водородных связей говорит и способность соединений $\left[\mathrm{Co}\left(\mathrm{NH}_{3}\right)_{6}\right]$ $\left[\mathrm{Cr}\left(\mathrm{C}_{2} \mathrm{O}_{4}\right)_{3}\right] 3 \mathrm{H}_{2} \mathrm{O}, \quad\left[\mathrm{Co}\left(\mathrm{NH}_{3}\right)_{6}\right]\left[\mathrm{Cr}\left(\mathrm{C}_{2} \mathrm{O}_{4}\right)_{3}\right] \cdot 3 \mathrm{H}_{2} \mathrm{O}$, и $\left[\mathrm{Co}(\mathrm{en})_{3}\right]\left[\mathrm{Cr}_{2}\left(\mathrm{C}_{2} \mathrm{O}_{4}\right)_{3}\right] \cdot 3 \mathrm{H}_{2} \mathrm{O}$, сохранять часть кристаллизационной воды при $110{ }^{\circ} \mathrm{C}$.

15 кристаллизуется в орторомбической системе. Это соединение также имеет островную структуру, в которой молекулы воды занимают кристаллографически независимые позиции и, по утверждению авторов [6], при нагревании выделяются в одну стадию. Установлено также, что молекулы воды располагаются внутри эллипсоидальных туннелей, параллельных оси $c$, и создают огромное количество водородных связей, стабилизирующих структуру [6].
Количество молекул внешнесферной воды для ДКС 14 в разных работах различается: 0 [147], 1 [147], 2 [148, 171], нами было получено соединение с $2 \mathrm{H}_{2} \mathrm{O}$. В случае 8 в работе [147] предложена формула с 21,6 молекула, в данной работе - 15 .

Комплекс $[\mathrm{Cu}(\mathrm{en})]_{3}\left[\mathrm{Fe}(\mathrm{CN})_{6}\right]_{2} \cdot 6 \mathrm{H}_{2} \mathrm{O}^{172}$ кристаллизуется в моноклинной системе и состоит из асимметрических ячеек, составленных одним анионом $\left[\mathrm{Fe}(\mathrm{CN})_{6}\right]^{4-}$, одним ионом [Cuen $]^{2+}$ и двумя молекулами $\mathrm{H}_{2} \mathrm{O}$. Атомы меди существуют в координации $\mathrm{CuN}_{5}$, создаваемой двумя атомами азота двух равноценных мостиковых молекул рп и тремя атомами азота цианогрупп, в виде искаженной квадратной пирамиды. Ион $\mathrm{Fe}^{2+}$ имеет почти правильную октаэдрическую координацию и связан с 6 ионами меди шестью цианомостиками, тогда как каждый ион меди связан с 3 эквивалентными ионами железа. Структура является трехмерной [172]. Предположительно, аналогичным строением обладает 26. В работах $[173,174]$ описаны близкие по составу к полученным нами ДКС $[\mathrm{Cutn}]_{2}\left[\mathrm{Fe}(\mathrm{CN})_{6}\right] \cdot \mathrm{KCl} \cdot 5 \mathrm{H}_{2} \mathrm{O}$ (A) и $[\mathrm{Cupn}]_{2}\left[\mathrm{Fe}(\mathrm{CN})_{6}\right] \cdot\left[\mathrm{Na}_{3} \mathrm{Fe}(\mathrm{CN})_{6}\right] \cdot 12 \mathrm{H}_{2} \mathrm{O}$ (Б), по структуре аналогичные 27. Все они содержат бесконечные слои $[\mathrm{Cupn}]_{2}\left[\mathrm{Fe}(\mathrm{CN})_{6}\right]$, которые могут быть рассмотрены как 2D слои, образованные дефектными кубическими единицами $\mathrm{Cu}_{4} \mathrm{Fe}_{3}$, включающие мостики $\mathrm{Cu}-\mathrm{CN}-\mathrm{Fe}$. Межслоевое пространство занято примесными ионами и молекулами воды. Эти нейтральные слои упакованы, перекрываясь вдоль кристаллографической оси ([001] для А и [100] для Б), образуя бесконечные тетрагональные туннели.

Согласно результатам PCA $\left[\mathrm{Ni}^{\mathrm{II}}(\mathrm{pn})_{2}\right]_{5}\left[\mathrm{Fe}^{\mathrm{III}}\right.$ $\left.(\mathrm{CN})_{6}\right]_{2}\left[\mathrm{Fe}^{\mathrm{II}}(\mathrm{CN})_{6}\right] \cdot 10 \mathrm{H}_{2} \mathrm{O} \quad$ [172], все цианогруппы $\left[\mathrm{Fe}(\mathrm{CN})_{6}\right]^{4-}$ включены в координацию соседних ионов никеля, и две цианогруппы $\left[\mathrm{Fe}(\mathrm{CN})_{6}\right]^{3-}$ связаны также с ионами никеля. Асимметричная структурная единица содержит 5 транс-[Ni $\left.{ }^{\mathrm{II}}(\mathrm{pn})_{2}\right]^{2+}$ катионов, два аниона $\left[\mathrm{Fe}(\mathrm{CN})_{6}\right]^{3-}$, один $\left[\mathrm{Fe}(\mathrm{CN})_{6}\right]^{4-}$ и 10 молекул воды. $\left[\mathrm{Fe}(\mathrm{CN})_{6}\right]^{3-}$ связан с двумя катионами, $\left[\mathrm{Fe}(\mathrm{CN})_{6}\right]^{4-}-$ c 6 катионами, образуя 3D структуру каркаса, содержащую связи $\mathrm{Fe}^{\mathrm{III}}-\mathrm{CN}-\mathrm{Ni}^{\mathrm{II}}$ и $\mathrm{Fe}^{\mathrm{II}}-\mathrm{CN}-\mathrm{Ni}^{\mathrm{II}}$. Комплексный катион никеля представляет собой сплюснутый тетрагонально искаженный октаэдр с 4 атомами азота из аминолиганда и двумя азотами цианогрупп. Геометрия аниона $\mathrm{Fe}(\mathrm{III})$ слабо отклоняется от октаэдрической. Нами получено соединение 19, содержащее не 10 , а 9 молекул $p n$, и 9 молекул воды вместо 10, как в исследовании [175].

В ранее упомянутой работе [142] приведено большое количество данных по кристаллическим структурам типа $\left[\mathrm{NiL}_{\mathrm{a}}\right]_{\mathrm{x}}\left[\mathrm{Fe}(\mathrm{CN})_{6}\right]_{\mathrm{y}} \cdot \mathrm{Z} \cdot \mathrm{kH}_{2} \mathrm{O}$, где $\mathrm{a}=1,2, \mathrm{x}=2,3, \mathrm{y}=1,2, \mathrm{k}=0-22,5, \mathrm{~L}=\mathrm{en}, \mathrm{tn}$, pn и другие (еще 13 видов лигандов), $\mathrm{Z}=\mathrm{ClO}_{4}$, 
$\mathrm{BF}_{4}$, I, NCS и другие. Показано, что структура в зависимости от природы лигандов и внешнесферных ионов может изменяться от островной, состоящей из пентаядерных кластеров типа $\mathrm{M}_{3}^{\mathrm{I}} \mathrm{M}^{\mathrm{II}}{ }_{2}$, например, $\left[\mathrm{Ni}\left(2,2^{\prime} \text {-piby }\right)_{2}\right]_{3}\left[\mathrm{Fe}(\mathrm{CN})_{6}\right]_{2} \cdot 13 \mathrm{H}_{2} \mathrm{O}$ до $3 \mathrm{D}-[\mathrm{Ni}(\mathrm{dipn})]_{3}\left[\mathrm{Fe}(\mathrm{CN})_{6}\right]_{2} \cdot 7 \mathrm{H}_{2} \mathrm{O}$, где dipnдипропилентриамин. В работах $[167,168]$ нами определены кристаллические структуры ДКС 20,
22-24, 29 и 30. Кристаллические структуры ДКС 20, 22 и 24 описываются в рамках триклинной сингонии, а 23 - ромбической сингонии. Все структуры островные, состоящие из независимых катионов и анионов. Соединения 20 и 22 изоструктурны. Структурные единицы и упаковка для соединений 20 и 23 представлены на рис. 9, 10. Кристаллические структуры ДКС 29 и 30 описываются в рамках
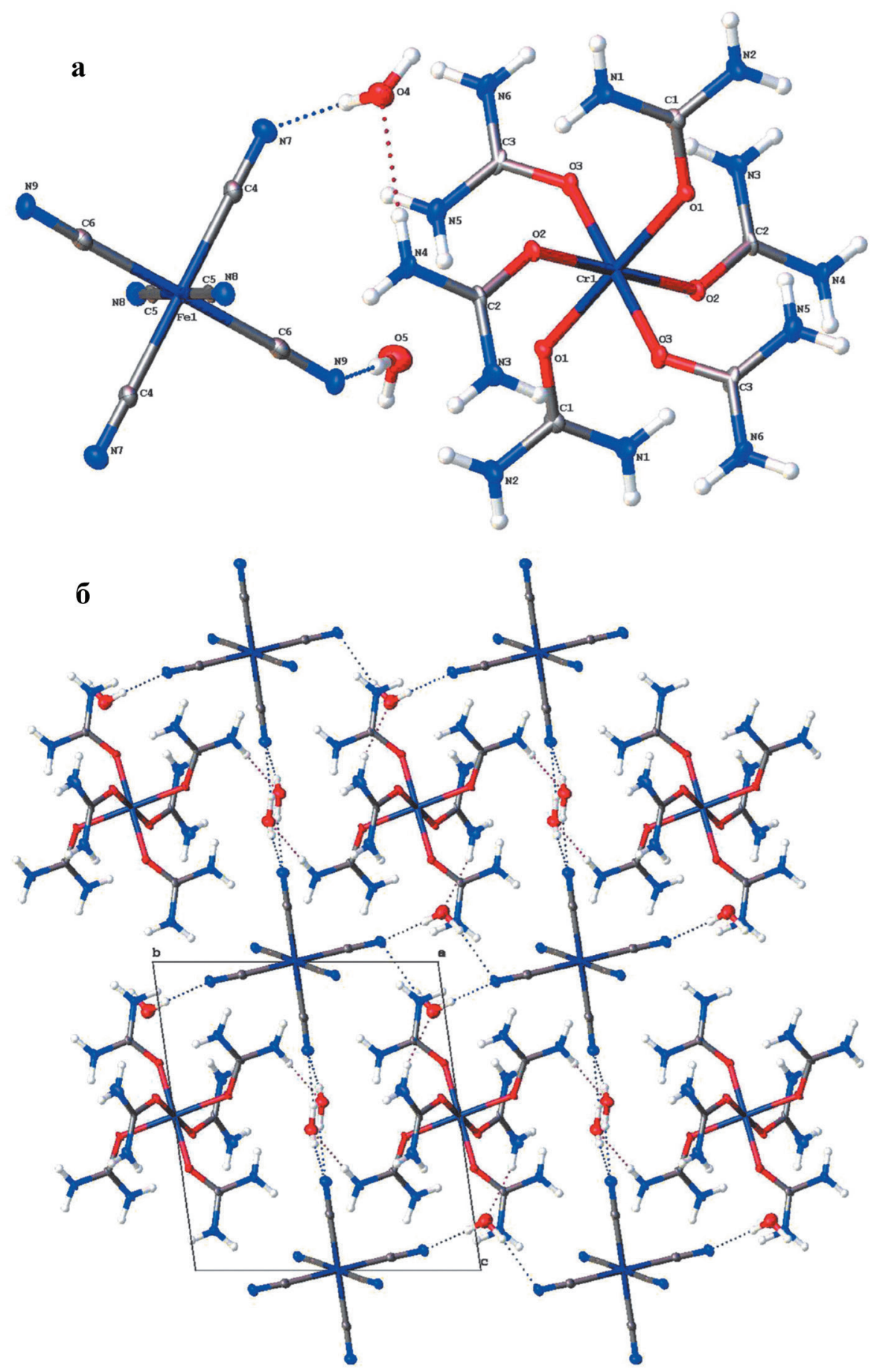

Рис. 9. Строение кристаллографически независимой части (а); и упаковка комплексных катионов и анионов в структуре на проекции перпендикулярной оси а (б) ДКС $\left[\mathrm{Cr}(\mathrm{ur})_{6}\right]\left[\mathrm{Fe}(\mathrm{CN})_{6}\right] \cdot \mathbf{4} \mathrm{H}_{2} \mathrm{O}$

Эллипсоиды тепловых колебаний изображены на уровне вероятности $50 \%$.

Водородные связи показаны пунктирными линиями 
моноклинной сингонии, являются островными и чрезвычайно сходны между собой.

Изученные ДКС, согласно имеющимся данным об их структуре и структуре их аналогов и близких к ним по составу соединений, следует разделить на 2 группы. К первой группе относятся соединения заведомо островной структуры, то есть не имеющие прочных мостиковых связей, кристаллическая решетка которых состоит из изолированных неискаженных или мало искаженных октаэдрических ионов, имеющие в структуре разве что водородные и Ван-дер-Ваальсовы связи. Примерами таких соединений являются
$1,4,6,11-14,20,22-24,29,30$. Ко второй группе отнесем ДКС, катионы которых имеют не вполне заполненную внутреннюю сферу, что приводит к обобщению молекул рn и цианогрупп и повышает роль кристаллизационной воды в структуре, например, ДКС 8-10, 16-19, 26-28. Рассматривая кривые термического анализа изученных ДКС применительно к кристаллической структуре, находим, что все кривые для ДКС, относящихся к одной и той же структурной группе, очень похожи друг на друга. ДКС первой группы, как в атмосфере воздуха, так и в аргоне, обезвоженные до $100{ }^{\circ} \mathrm{C}$, устойчивы до $\sim 200{ }^{\circ} \mathrm{C}$,
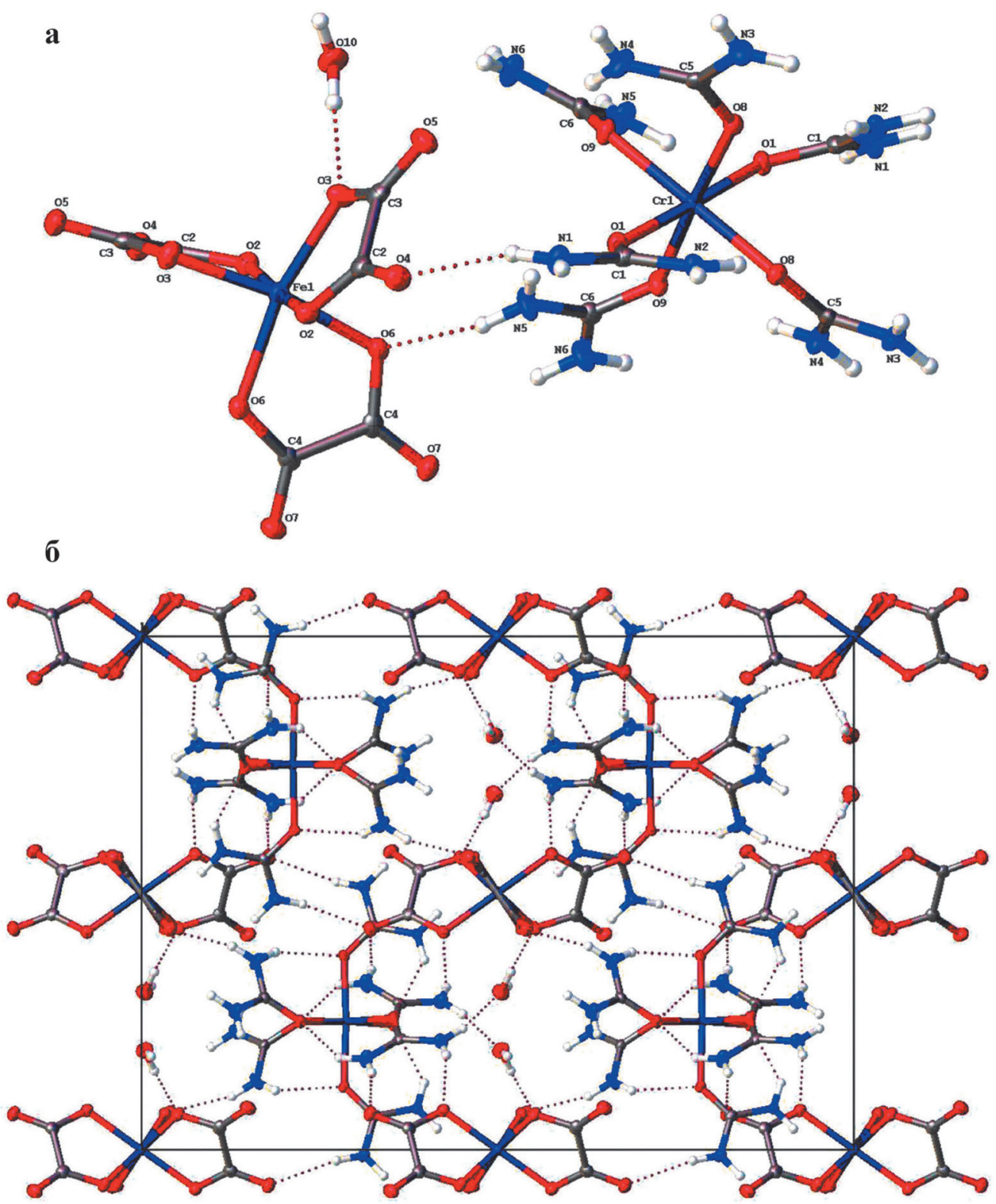

Рис. 10. Строение кристаллографически независимой части (а); и упаковка комплексных катионов и анионов в структуре на проекции перпендикулярной оси а (б) ДКС $\left[\mathrm{Cr}(\mathrm{ur})_{6}\right]\left[\mathrm{Fe}(\mathrm{Ox})_{3}\right] \cdot 2 \mathrm{H}_{2} \mathrm{O}$

Эллипсоиды тепловых колебаний изображены на уровне вероятности $50 \%$. Водородные связи показаны пунктирными линиями 
ТГ, мacc. $\%$

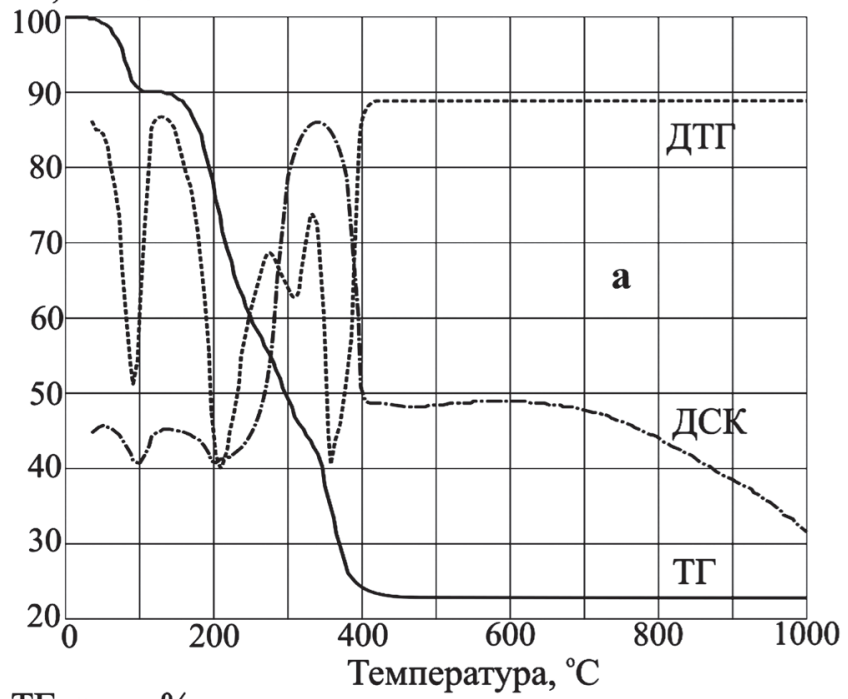

ТГ, мacc. $\%$

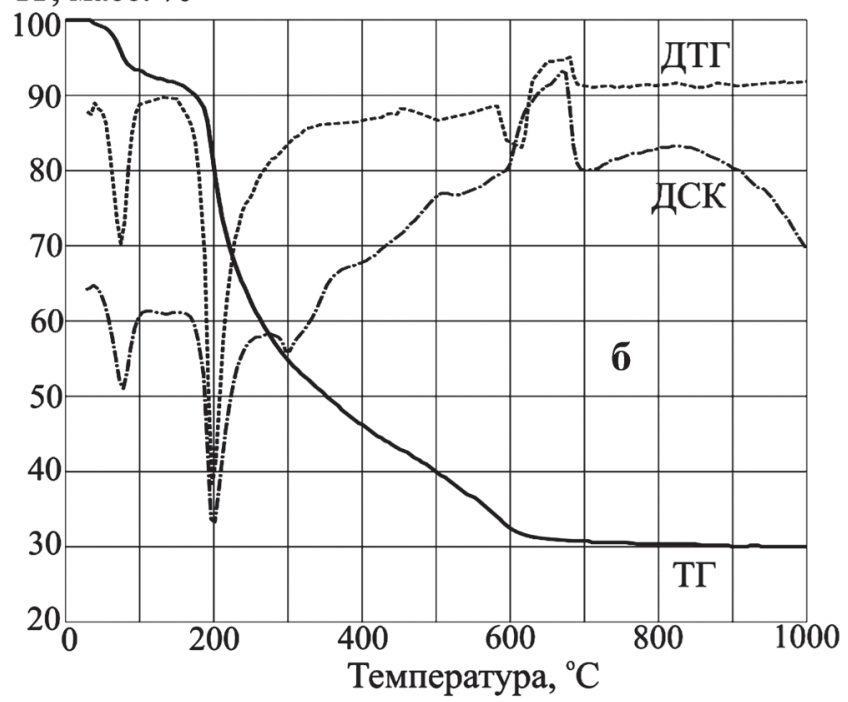

Рис. 11. Обобщенные кривые термического анализа ДКС в атмосфере:

а) воздуха; б) аргона после чего наступает плавная потеря массы без выраженных стадий. Для обеих групп в атмосфере воздуха наблюдается широкий экзотермический эффект (рис. 11a) в интервале 300-450 ${ }^{\circ} \mathrm{C}$, связанный с окислением (сгоранием) углеродных компонентов ДКС. В инертной атмосфере наблюдается большой эндотермический эффект в области 200-300 ${ }^{\circ} \mathrm{C}$ (рис. 11б). Потеря массы в атмосфере аргона продолжается почти до $1000{ }^{\circ} \mathrm{C}$. Для цианидных ДКС характерно одновременное выделение всех ГПТР в области 200-300 ${ }^{\circ} \mathrm{C}$ и потеря азота около 600-670 ${ }^{\circ} \mathrm{C}$. Для инертной атмосферы и воздуха характерно выделение $\mathrm{NH}_{3}$ и $\mathrm{HCN}$, для $\left[\mathrm{Cr}(\mathrm{ur})_{6}\right]\left[\mathrm{Fe}(\mathrm{CN})_{6}\right] \cdot 3 \mathrm{H}_{2} \mathrm{O}$ и $\left[\mathrm{Cr}(\mathrm{ur})_{6}\right]\left[\mathrm{Co}(\mathrm{CN})_{6}\right] \cdot 3 \mathrm{H}_{2} \mathrm{O}$ - также $\mathrm{HNCO}$ и ur, а для $\left[\mathrm{Co}(\mathrm{en})_{3}\right]\left[\mathrm{Fe}(\mathrm{CN})_{6}\right] \cdot 2 \mathrm{H}_{2} \mathrm{O}-\mathrm{en}$.

Кривые термического анализа для второй группы значительно отличаются от соответствующих кривых ДКС 1 группы. Во-первых, разложение с потерей кристаллической структуры у них во всех атмосферах начинается при нагревании от 60-80 ${ }^{\circ} \mathrm{C}$, причем ДКС сразу теряют свою индивидуальность. На кривых ТГ и ДТГ наблюдается ряд четко выраженных стадий - пиков ДТГ, которых насчитывается 4-5 против 2-3 для первой группы. Сравнение термического поведения ДКС различных структурных типов показывает, что ДКС островной структуры более термически устойчивы, чем ДКС 1, 2 и 3D-структуры. То есть, наличие сложного каркаса, созданного мостиковыми связями, понижает термическую устойчивость ДКС. ДКС со сложной каркасной структурой разрушает даже слабое нагревание.

На основании анализа литературного материала и проведенных систематических исследований процесс термического разложения

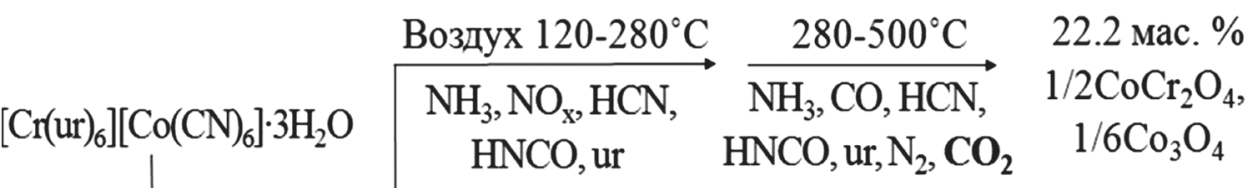

$$
\begin{aligned}
& 120^{\circ} \mathrm{C} \mid-3 \mathrm{H}_{2} \mathrm{O}
\end{aligned}
$$

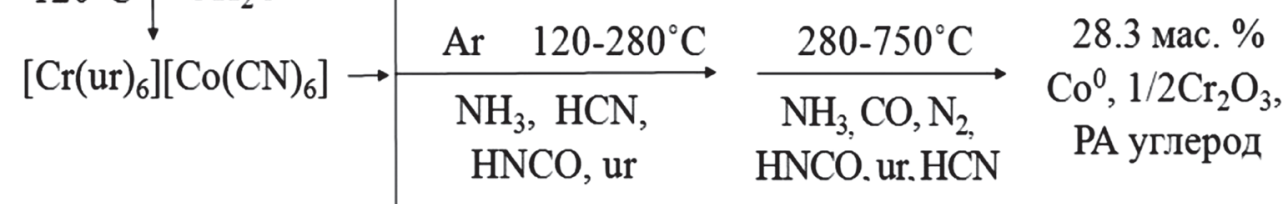

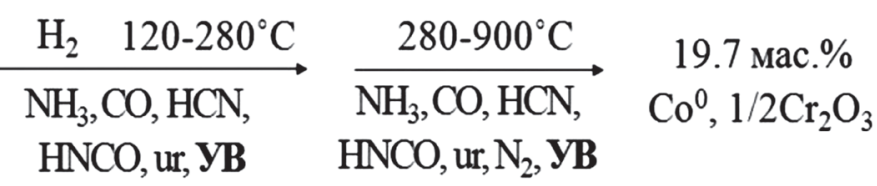

Рис. 12. Схема разложения ДКС на примере $\left[\mathrm{Cr}(\mathrm{ur})_{6}\right]\left[\mathrm{Co}(\mathrm{CN})_{6}\right] \cdot 3 \mathrm{H}_{2} \mathrm{O}$

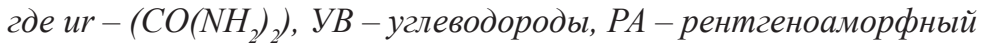


ДКС $\left[\mathrm{M}^{1} \mathrm{~L}_{6}\right]_{\mathrm{x}}\left[\mathrm{M}^{2} \mathrm{X}_{6}\right]_{\mathrm{y}} \cdot \mathrm{nH}_{2} \mathrm{O}\left(\mathrm{L}=\right.$ ur, tn, en, $\mathrm{X}-\mathrm{CN}^{-}, 1 / 2$ $\left.\mathrm{C}_{2} \mathrm{O}_{4}{ }^{2-}, \mathrm{NO}_{2}{ }^{-}\right)$можно представить следующим образом, по мере повышения температуры.

1. Обезвоживание ДКС с разрывом водородных связей.

2. Разрушение кристаллической структуры ДКС с одновременным распадом катиона и аниона.

3. Лиганды $\mathrm{L}$ в результате распада катионной части ДКС в свободном виде равномерно распределяются в массе остатка и частично выделяются в газовую фазу в свободном виде, а частично подвергаются деструкции.

4. Анионная часть ДКС разлагается таким образом, что остаются цианиды или оксалаты $\mathrm{M}^{2}$, которые затем распадаются либо на $\mathrm{N}_{2}$ и углерод (цианиды), либо с выделением $\mathrm{CO}_{2}$ и СО (оксалаты), отдавая часть кислорода ц.и. Эти продукты остаются в системе, если отсутствует возможность реакции между L и X, как в ДКС $\left[\mathrm{Cr}(\mathrm{ur})_{6}\right]\left[\mathrm{Co}\left(\mathrm{NO}_{2}\right)_{6}\right]$, и если газовая среда не содержит реагента (инертная среда), способного взаимодействовать с ними и с ц.и.

5. Если в атмосфере есть такой реагент $\left(\mathrm{O}_{2}\right.$ или $\mathrm{H}_{2}$ ), продукты термолиза и ц.и. продолжают реагировать с ним до образования устойчивых соединений (оксидов или металлов).

Пример процесса термического разложения ДКС представлен на рисунке 12.

Пока внутренняя сфера катионов и анионов ДКС не вполне разрушена, природа газовой атмосферы не влияет на ход термолиза. Различия в ходе термолиза в зависимости от атмосферы - это результат взаимодействия с атмосферой уже не ДКС, а продуктов его разложения, состав и соотношение которых зависит от первоначального состава ДКС, поэтому для получения функциональных материалов необходимо ориентироваться на первоначальный состав, но исследовать весь ход термолиза до установления постоянной массы остатка. Удаление летучих продуктов термолиза потоком газа вызывает сдвиг равновесия в сторону их образования, поэтому расхождения в составе продуктов, полученных в статическом и динамическом режиме, являются закономерными. Анализ приведенных в литературе данных показал, что термическая устойчивость ДКС не связана с их термодинамической устойчивостью в раствоpe, что, по-видимому, естественно, так как процесс термолиза обычно проводится в проточном реакторе с удалением части продуктов, и следовательно, является неравновесным. Видно, что никакие ДКС 3d-элементов не выдерживают нагревания выше $200-250{ }^{\circ} \mathrm{C}$, а после их разрушения ход процесса определяется свойствами остаточных твердых остаточных твердых продуктов. Термическая устойчивость ДКС еще понижается, если ц.и. обла- дает значительными окислительными свойствами, как, например, катион Сo(III), а лиганды - восстановительными свойствами.

\section{Лuтература}

1. Шубин Ю.В. Автореферат диссертации на соискание ученой степени доктора химических наук «Формирование и структурно-фазовые превращения наноразмерных биметаллических частиц на основе благородных металлов». Новосибирск. 2009.

2. Asanova T.I., Asanov I.P., Kim Min-Gyu, Gerasimov E.Yu., Zadesenets A.V., Plyusnin P.E., Korenev S.V. J. Nanopart. Res. 2013. V. 15. 15:1994.

3. Gubanov A.I., Filatov E.Yu., Semitut E.Yu., Smolentsev A.I., Snytnikov P.V., Potemkin D.I., Korenev S.V. Thermochim. Acta. 2013. V. 566. P. 100-104.

4. Гринберг А.А. Введение в химию комплексных соединений. Ленинград. Наука. 1966. 632 с.

5. Громилов С.А., Коренев С.В., Байдина И.А., Корольков И.В., Юсенко К.В. Журн. структур. химии. 2002. T. 43. C. 527.

6. Matikova-Malarova M., Černák J., Massa W., Varret F. Inorg. Chim. Acta. 2009. V. 362. P. 443.

7. Wang Sh., Ferbinteanu M., Yamashita M. Inorg. Chem. 2007. V. 46. P. 610-612.

8. Kou H.-Zh., Tang Jin-Kui, Liao Dai-Zheng, Gao Song, Cheng Peng, Jiang Zong-Hui, Yan Shi-Ping, Wang Geng-Lin, Chansou Benoît, Tuchagues Jean-Pierre. Inorg. Chem. 2001. V. 40. P. 4839-4844.

9. Fukita N., Ohba M., Ōkawa H., Matsuda K., Iwamura H. Inorg. Chem. 1998. V. 37. P. 842-848.

10. Васильченко Д.Б. Автореферат диссертации на соискание ученой степени кандидата химических наук «Синтез и исследование комплексных соединений родия(III) с лигандами пиридинового ряда» Новосибирск. 2011.

11. Zadesenets A.V., Asanova T.I., Vikulova E.S., Filatov E.Yu., Plyusnin P.E., Baidina I.A., Asanov I.P., Korenev S.V. J. Solid State Chem. 2013. V. 199. P. 71-77.

12. Венедиктов А.Б., Коренев С.В., Шубин Ю.В., Кузнецов И.А., Юсенко К.В. Журн. неорган. химии. 2003. T. 48. №3. С. 448-454.

13. Печенюк С.И., Домонов Д.П., Рогачев Д.Л., Беляевский А.Т. Журн. неорган. химии. 2007. Т. 52. №7. С. $1110-1115$.

14. Печенюк С.И., Домонов Д.П., Гостева А.Н., Кадырова Г.И., Калинников В.Т. Коорд. химия. 2012. T. 38. №9. С. 618-625.

15. Домонов Д.П., Печенюк С.И. Вестник ЮУрГУ. Серия Химия. 2016. Т. 8. С. 52.

16. George T.D., Wendlandt W.W. J. Inorg. Nucl. Chem. 1963. V. 25. P. 395-405.

17. Wendlandt W.W., Chou C.Y. J. Inorg. Nucl. Chem. 1964. V. 26. P. 943-949.

18. Zivkovic Z.D. J. Therm. Anal. 1994. V. 41. P. 99-104.

19. Rejitha K.S., Ishikawa T., Mathew S. J. Therm. Anal. Calorim. 2011. V. 103. P. 515-523.

20. Collins L.W., Wendlandt W.W., Gibson E.K. Thermochim. Acta. 1974. V. 8. P. 315-323. 
21. Mikuli E., Liszka M., Molenda M. J. Therm. Anal. Calorim. 2007. V. 89. P. 573-578.

22. Liszka-Scoszylas M., Mikuli E., Hetmanczyk J., Szklarzewicz J. Thermochim. Acta. 2009. V. 496. P. 38-44.

23. Liszka-Scoczylas M., Mikuli E., Szklarzewicz J., Hetmanczyk J. J. Therm. Anal. Calorim. 2010. V. 102. P. 889-897.

24. Mikuli E., Migdal-Mikuli A., Majda D. J. Therm. Anal. Calorim. 2013. V. 112. P. 1191-1198.

25. Farhadi S., Roostaei-Zaniyani Z. Polyhedron. 2011. V. 30. P. 1244-1249.

26. Hetmanczyk J., Hetmańczyk Ł., Migdał-Mikuli A., Mikuli E. J. Therm. Anal. Calorim. 2014. V. 118. P. 1049-1056.

27. Ingier-Stocka E. J. Therm. Anal. Calorim. 1993. V. 40. P. 1357-1365.

28. Ingier-Stocka E., Rycerz L. J. Therm. Anal. Calorim. 1999. V. 56. P. 547-552.

29. Wendlandt W.W., George T.D., Krishnamurty K.V. J. Inorg. Nucl. Chem. 1961. V. 21. P. 69-76.

30. Kohata S., Asakawa M., Maeda T., Shyo H., Ohyoshi A. Analytical Sciences. 1986. V. 2. P. 325.

31. Bucci R., Magri A.D., Magri A.L., Messina A. Thermochim. Acta. 1983. V. 60. P. 287-294.

32. Takamizawa S., Kohbara M., Akatsuka T., Miyake R. New J. Chem. 2008. V. 32. P. 1782-1787.

33. House J.E. Thermochim. Acta. 1985. V. 91. P. 61-66.

34. Liptay G., Wadsten T., Bordely-Kuszmann A. J. Therm. Anal. 1986. V. 31. P. 845-852.

35. Probhymiraski L.S., Natu G.N., Nayak S.R. J. Therm. Anal. 1989. V. 35. P. 1105-1110.

36. Probhymiraski L.S., Natu G.N., Khoje J.K. J. Therm. Anal. 1989. V. 35. P. 1097-1103.

37. Zsako J., Pokol G., Novák Cs.,. Várhelyi Cs, Dobó A., Liptay G. J. Therm. Anal. Calorim. 2001. V. 64. P. 843856.

38. Zeleňāk V., Orendaciova A., Cisarova I., Cernak J. Inorg. Chem. 2006. V. 45. P. 1774-1782.

39. De G., Kumar Biswas Pr., Chaudhuri N. Ray. Bull. Chem. Soc. Japan. 1983. V. 56. P. 3145.

40. Collins L., Wendlandt W.W. Thermochim. Acta. 1973. V. 7. P. 209-216.

41. Rejitha K.S., Mathew S. J. Therm. Anal. Calorim. 2008. V. 93. P. 213-217.

42. Rejitha K.S., Mathew S. J. Therm. Anal. Calorim. 2010. V. 102. P. 931-939.

43. Wendlandt W.W. J. Inorg. Nucl. Chem. 1963. V. 25. P. 833-842.

44. Zheng L., Dai L., Xin X. Thermochim. Acta. 1992. V. 196. P. 437-446.

45. Bowman P.B., Rogers L.B. J. Inorg. Nucl. Chem. 1966. V. 28. P. 2215-2224.

46. Справочник химика. Под ред. Никольского Б.П., Наука, Ленинград, 1964, Т. 2, 1168 с.

47. Лурье Ю.Ю. Справочник по аналитической химии. М.: Химия. 1971. 456 с.

48. Southern T.M., Wendlandt W.W. J. Inorg. Nucl. Chem. 1970. V. 32. 3783-3792.

49. Han Guo-Hua, Lin Bi-Zhou, Li Zhen, Sun Dong-Ya, Liu Pei-De. J. Mol. Struct. 2005. V. 741. P. 31.

50. Jia Ding-Xian, Zhang Yong, Dai Jie, Zhu Qin-Yu, Gua Xiao-Mei. J. Solid State Chem. 2004. V. 177. P. 24772483.
51. Mathew S., Nair C.G.R., Ninan K.N. Thermochim. Acta. 1991. V. 181. P. 253-268.

52. Smith J.P., Wendlandt W.W. J. Inorg. Nucl. Chemistry. 1964. V. 26. P. 1157-1163.

53. Oms M.T., Forteza R., Cerda V., Bordull F. Thermochim. Acta. 1989. V. 138. P. 1-12.

54. Kanesaka I., Nishimura H., Kanamori K., Ichimura K., Watanabe K., Kawai K. Annual Report of Tritium research Center. Toyama Universiry. 1986. V. 6. P. 71 .

55. Печенюк С.И., Шимкин А.А., Кривцов И.В., Гостева А.Н., Авдин А.А. Вестник ЮУрГу. Серия Химия. 2014. T. 6. №4. C. 29-40.

56. Schaber P.M., Colson J., Higgins S., Thielen D., B.Anspach, Brauer J. Thermochim. Acta. 2004. V. 424. P. 131-142.

57. Janicki H., Blotny G., Bator-Sawicka B., Dobrowolski J. J. Therm. Anal. 1976. V. 9. P. 401-404.

58. Gorska N., Mikuli E., Kotal L. Eur. Chem. Bull. 2014. V. 3. P. 474.

59. Stojceva Radovanovic B.C., Premovic P.I. J. Therm. Anal. 1992. V. 38. P. 715-719.

60. Orlova V.T., Kudinov I.B., Kosterina V.I., Semendyaeva N.K., Lepeshkov I.N. J. Therm. Anal. 1985. V. 30. P. 1047-1051.

61. Carp O., Patron L., Segal E. Revue Roumaine Chem. 2006. V. 51(1). P. 5.

62. Carp O., Patron L., Brezeanu M. J. Therm. Anal. Calorim. 1999. V. 56. P. 561-568.

63. Carp O., Patron L., Reller A. J. Therm. Anal. Calorim. 2003. V. 73. P. 867-876.

64. Печенюк С.И., Гостева А.Н. Коорд. химия. 2014. Т. 40. № 8 С. 476-486.

65. Печенюк С.И., Домонов Д.П. Журн. структ. химии. 2011. T. 52. C. 419.

66. Кукушкин Ю.Н., Буданова В.Ф., Седова Г.Н. Термические превращения координационных соединений в твердой фазе. Ленинград. ЛГУ. 1981. 176 с.

67. Ормонт Б.Ф., Петров Б.А. Журн. физ. химии. 1933. T. 4. C. 706.

68. Ормонт Б.Ф., Петров Б.А. Журн. физ. химии. 1935, T. 6. C. 695.

69. Петров Б.А., Ормонт Б.Ф. Журн. прикл. химии. 1935. T. 8. C. 1330.

70. Сейфер Г.Б. Журн. неорг. химии. 1960. Т. 5. С. 68.

71. Сейфер Г.Б., Белова В.И., Макарова 3.А. Журн. неорг. химии. 1964. Т. 9. С. 1556.

72. Nawazish A. Khan, Baber N., Iqbal M. Zafar, Mazhar M. Chem. Mater. 1993. V. 5. P. 1283-1286.

73. Chamberlain M.M., Greene A.F. J. Inorg. Nucl. Chem. 1963. V. 25. P. 1471-1475.

74. Mohai B., Bagyin L. J. Inorg. Nucl. Chem. 1971. V. 33. P. 3311-3321.

75. Mohai B. Z. anorg. allg. Chemie. 1972. V. 392. P. 287.

76. Wolski W., Porawski W. J. Therm. Anal. 1975. V. 7. P. 139-147.

77. Wolski W., Porawski W. J. Therm. Anal. 1976. V. 9. P. 181-190.

78. Brar A.S., Sandhu H.S., Sandhu S.S. J. Therm. Anal. 1983. V. 26. P. 7-15.

79. Bristoti A., Bonilla I.R., Andade P. da R. J. Therm. Anal. 1976. V. 9. P. 93-99. 
80. Chen H., Xin X., Niu J., Dai A., Tail P., Wang X., Zhang Y. Chem. J. Chinese Univ. (Eng. Ed.) 1988. V. 4. P. 8.

81. Печенюк С.И., Домонов Д.П., Шимкин А.А., Иванов Ю.В. Изв. РАН. Серия хим. 2015. №2. С. 322.

82. Kunrath J.I., Muller C.S., Frank E. J. Therm. Anal. 1978. V. 14. P. 253-264.

83. Marco D. De, Marchese A., Migliardo P., Bellomo A. J. Therm. Anal. 1987. V. 32. P. 927-937.

84. Lehto J., Pettersson M., Hinkula J., Rasanen M., Elomaa M. Thermochim. Acta. 1995. V. 265. P. 25-30.

85. Tkaversa E., Sakamoto M., Sadaoka Y. J. Am. Ceram. Soc. 1995. V. 79. p. 1401.

86. Sadaoka Y., Watanabe K., Sakai Y., Sakamoto M. J. Alloys and Compounds. 1995. V. 224. P. 194-198.

87. Masuda Y., Seto Y., Wang X., Tuchiya Y. J. Therm. Anal. Calorim. 2001. V. 64. P. 1045-1051.

88. Seto Y., Nagao S., Wang X., Masuda Y. J. Therm. Anal. Calorim. 2003. V. 73. P. 755-762.

89. Seto Y., Umemoto K., Arii T., Masuda Y. J. Therm. Anal. Calorim. 2004. V. 76. P. 165-177.

90. Aono H., Traversa E., Sakamoto M., Sadaoka Y. Sensors and Actuators. B. 2003. V. 94. P. 132.

91. Goubard F., Tabuteau Al. Structural Chem. 2003. V. 14. P. 257-262.

92. Gil D.M., Carbonio R.E., Gómez M.I. J. Mol. Struct. 2013. V. 1041. P. 23-28.

93. Ng C.W., Ding J., Wang L., Gan L.M., Quik C.H. J. Phys. Chem. A. 2000. V. 104. P. 8814.

94. Ng C.W., Ding J., Shi Y., Gan L.M. J. Physics and Chem. of Solids. 2001. V. 62. P. 767.

95. Ng C.W., Ding J., Gan L.M. J. Solid State Chem. 2001. V. 156. P. 400-407.

96. Etcheverry S.B., Baran E.J. Thermochim. Acta. 1987. V. 111. P. 375-377.

97. Cyganski A., Krystek J., Ptaszynski B. Thermochim. Acta. 1994. V. 231. P. 143-149.

98. Mimura H., Lehto J., Harjula R. J. of Nuclear Science and Technology. 1997. V. 34. P. 582.

99. Navarro M.C. Global J. of Inorg. Chem. 2010. V. 1. P. 76.

100. Jinhua Y., Xinquan X., Anbang D. Thermochim. Acta. 1988. V. 130. P. 77-85.

101. Tanaka N., Nanio N. Bull. Chem. Soc. Japan. 1967. V. 40. P. 330.

102. Broadbent D., Dollimore D., Dollimore J. J. Chem. Soc. (A): Inorg. Phys. Theor. 1967. P. 451.

103. Banckroft D.M., Dharmawardena K.G., Maddock A.G. Inorg. Chem. 1970. V. 9. P. 223-226.

104. Sanyal T.K., Dass N.N. J. Inorg. Nucl. Chem. 1980. V. 42. P. 811-813.

105. Usha M.G., Subba Rao M., Narayanan Kutty T.R. J. Therm. Anal. 1986. V. 31. P. 7-14.

106. Jinhua Y., Xinquan X., Anbang D., Yuchang Ch. Thermochim. Acta. 1988. V. 126. P. 51-60.

107. Jin Li, Feng-Xing Z., Jan-Wei R. Yong-Qian H., Ye-Fei $N$. Thermochim. Acta. 2003. V. 406. P. 77-87.

108. Wendlandt W.W., Southern M. J. Therm. Anal. 1970. V. 2. P. 87-89.

109. Cyganski A., Furmaniak A. Thermochim. Acta. 1985. V. 84. Р. 19-31.

110. Домонов Д.П. Диссертация на соискание ученой степени кандидата химических наук «Исследование термического разложения двойных комплексных соединений металлов первого переходного ряда». Новосибирск. 2009.

111. Aparicio C., Machala L., Marusak Z. J. Therm. Anal. Calorim. 2012. V. 110. P. 661-669.

112. Buser H.J., Schwarzenbach D., Petter W., Ludi A. Inorg. Chem. 1977. V. 16. P. 2704-2710.

113. Смирнов И.И., Рюмин А.И., Чумаков В.Г., Волкова Г.В. Журн. неорг. химии. 1981. Т. 26. С. 2249.

114. Смирнов И.И., Рюмин А.И., Чумаков В.Г., Волкова Г.В. Журн. неорг. химии. 1981. Т. 26. С. 2178.

115. Шубочкин Л.К., Большакова Л.Д., Шубочкина Е.Ф., Максимова С.И., Смирнов И.И. Коорд. химия. 1986. T. 12. C. 372.

116. Шубин Ю.В., Коренев С.В. Журн. неорган. химии. 2002. T. 47. № 11. С. 1812-1816.

117. Юсенко К.В., Громилов С.А., Байдина Е.А., Шубин Ю.В., Корольков И.В., Дребущак Т.Н., Басова Т.В., Коренев С.В. Журн. структур. химии. 2002. Т. 43. C. 699.

118. Шубин Ю.В., Коренев С.В., Юсенко К.В., Корда Т.М., Венедиктов А.Б. Изв. АН, Сер. хим. 2002. № 1. С. 39.

119. Плюснин П.Е., Байдина И.А., Шубин Ю.В., Коренев С.В. Журн. неорган. химии. 2005. Т. 50. № 12. C. 1959-1965.

120. Плюснин П.Е., Байдина И.А., Шубин Ю.В., Коренев С.В. Журн. неорган. химии. 2007. Т. 52. №3. С. 421427.

121. Плюснин П.Е., Байдина И.А., Шубин Ю.В., Коренев С.В. Журн. неорган. химии. 2008. Т. 53. № 11. C. 1844-1852.

122. Семитут E.Ю. Диссертация на соискание ученой степени кандидата химических наук «Двойные комплексные соли золота(III): синтез, структура, термические свойства». Новосибирск. 2014.

123. Юсенко К.В., Корольков И.В., Громилов С.А., Коренев С.В. Журн. структур. химии. 2007. Т. 48. С. 385.

124. Мартынова С.А., Юсенко К.В., Корольков И.В., Громилов С.А. Коорд. химия. 2007. Т. 33. №7. С. 541-545.

125. Мартынова C.A. Диссертация на соискание ученой степени кандидата химических наук «Синтез и исследование соединений-предшественников металлических рутений-содержащих систем с Pt, Ir, Os, $\mathrm{Re}, \mathrm{Cu}$ ». Новосибирск. 2015.

126. Плюснина О.А., Емельянов В.А., Байдина И.А., Корольков И.В., Громилов С.А. Журн. структур. химии. 2007. T. 48. C. 114.

127. Шубочкин Л.К., Большакова Л.Д., Шубочкина Е.Ф. Журн. неорган. химии. 1989. Т. 34. № 1. С. 255-258.

128. Большакова Л.Д., Ларин Г.М., Минин В.В., Зверева Г.А., Шубочкин Л.К., Ракитин Ю.В., Вальковский М.Д. Журн. неорган. химии. 1992. Т. 37 . №7. C. $1542-1546$.

129. Большакова Л.Д., Лапкин В.В. Журн. неорган. химии. 1997. №9. Т. 42. С. 1497-1501.

130. Макотченко Е.В., Байдина И.А., Плюснин П.Е. Журн. структур. химии. 2007. Т. 48. 282.

131. Якушев И.А. Диссертация на соискание ученой степени кандидата химических наук «Синтез и физико-химические свойства гетерометаллических карбоксилатных комплексов палладия(II) с Nи О-основаниями». Москва. 2015. 
132. Chomic J., Cernak J., Potocnak I. Chem. Papers. 1993. V. 47. P. 175.

133. Кукушкин Ю.Н., Калюкова Е.Н., Естратова Е.Ф. Коорд. химия. 1983. Т. 9. С. 1107.

134. Chomic J., Cernak J., Safarik P.J. Thermochim. Acta. 1985. V. 93. P. 93-96.

135. Sollberger B., Reller A., Oswald H.R. Thermochim. Acta. 1985. V. 85. P. 51-54.

136. Potocnak I., Vavra M., Cizmar E., Tibenská K., Orendáčová A., Steinborn D., Wagner C., Dušek M., Fejfarová K., Schmidt H., Mu"ller T., Orendáč M., Feher A. J. Solid State Chem. 2006. V. 179. P. 1965-1976.

137. Legendre A.O., Correa J.R.A., Bannach G., Mauro A.E., Ionashiro M. J. Therm. Anal. Calorim. 2007. V. 87. P. 779-782.

138. Zadesenets A.V., Filatov E.Yu., Yusenko K.V., Shubin Yu.V., Korenev S.V., Baidina I.A. Inorg. Chim. Acta. 2008. V. 361. P. 199.

139. Cernak J., Skorsepa J., Chomic J., Potocnák I., Hoppan J. J. Therm. Anal. 1994. V. 41. P. 91-98.

140. Horvath A., Mohai B. J. Inorg. Nucl. Chem. 1980. V. 42. P. 195-199.

141. Пирский Ю.К., Кублановский В.С., Березовская А.В., Безнищенко А.А., Кокозей В.Н., Маханькова В.Г. Доп. НАН Украіни. 2008. №6. С. 133.

142. Hershel R., Tucek J., Travnicek Z. Inorg. Chem. 2011. V. 50. P. 9153-9163.

143. Korkmaz A., Karadag A., Yerlic Yu. New J. Chem. 2014. V. 38. P. 5402.

144. Nami Sh.A.A., Husain A., Siddiqi K.S., Westcottc B.L., Kopp-Vaughnc K. Spectrochim. Acta Part A:. 2010. V. 75. P. 444.

145. Жидкова Н.М., Илюхин А.Б., Котов В.Ю., Степина И.A., Lin P.-H., Murugesu M. Журн. неорган. химии. 2011. T. 56. №2. C. 297-300.

146. Rehbein M., Epple M., Fischer R.D. Solid State Sciences. 2000. V. 2. P. 473-488.

147. Malarova M., Travnićek M.Z., Zboril R., Černák J. Polyhedron. 2006. V. 25. P. 2935-2943.

148. Travnićek Z., Zboril R., Matikova-Mal'arova M., Drahoš B., Černák J. Chemistry Central Journal. 2013. V. 7. P. 28.

149. Кузьмич Ю.В., Колесникова И.Г., Печенюк С.И., Семушина Ю.П., Серба В.И., Фрейдин Б.М. Перспективные Материалы. 2005. № 1. С. 92.

150. Печенюк С.И., Семушина Ю.П., Кадырова Г.И., Рогачев Д.Л., Кузьмич Л.Ф., Домонов Д.П., Калинников В.Т. Коорд. химия. 2005. Т. 31. № 12. С. 912-917.

151. Печенюк С.И., Семушина Ю.П., Домонов Д.П., Михайлова Н.Л. Коорд. химия. 2006. Т. 32. №8. С. 597-600.

152. Кузьмич Ю.В., Колесникова И.Г., Домонов Д.П., Серба В.И., Фрейдин Б.М. Журн. Российские нанотехнологии. 2007. №2. С. 109.

153. Домонов Д.П., Печенюк С.И., Михайлова Н.Л., Беляевский А.Т. Журн. неорган. химии. 2007. Т. 52. №3. C. 1104-1109.

154. Домонов Д.П., Печенюк С.И., Рогачев Д.Л., Беляевский A.T. Термическое разложение $\left[\mathrm{Co}\left(\mathrm{NH}_{3}\right)_{6}\right]$
$\left[\mathrm{Cr}(\mathrm{NCS})_{6}\right] \cdot 3.5 \mathrm{H}_{2} \mathrm{O}$. Москва. 2007. 14 с. деп. в ВИНИТИ 28.05.2007. № 576-В2007.

155. Домонов Д.П., Печенюк С.И., Беляевский А.Т. Термическое разложение некоторых двойных комплексов, содержащих катион $\left[\mathrm{Ni}\left(\mathrm{NH}_{3}\right)_{6}\right]^{2+}$. Москва. 2007. 17 с. деп. в ВИНИТИ 31.07.2007. № 797-В2007.

156. Печенюк С.И., Домонов Д.П., Беляевский А.Т. Журн. неорган. химии. 2008. Т. 53. №8. С. 1313-1319.

157. Домонов Д.П., Печенюк С.И., Куратьева Н.В. Журн. структ. химии. 2011. Т. 52. С. 365.

158. Печенюк С.И., Домонов Д.П., Аведисян А.А., Икорский С.В. Журн. неорган. химии. 2010. Т. 55. №5. C. 788-792.

159. Семушина Ю.П., Печенюк С.И., Михайлова Н.Л., Иванов И.В. Коорд. химия. 2015. Т. 41. №3. С. 157162.

160. Семушина Ю.П., Плюснин П.Е., Шубин Ю.В., Печенюк С.И., Иванов Ю.В. Изв. РАН. Серия хим. 2015. №8. С. 1963-1966.

161. Печенюк С.И., Домонов Д.П., Гостева А.Н., Кадырова Г.И., Михайлова Н.Л. Изв. СПбГИ(ТУ). 2012. № 15(41). С. 18-22.

162. Печенюк С.И., Семушина Ю.П., Гостева А.Н., Домонов Д.П., Кадырова Г.И. Известия ВУЗов. Журнал химия и хим. технология. 2016. Т. 59. С. 55-62.

163. Печенюк С.И., Гостева А.Н., Домонов Д.П., Макарова Т.И. Вестник ЮУрГУ. Серия химия. 2012. Т. 9. №24. С. 4-12.

164. Печенюк С.И., Домонов Д.П., Шимкин А.А. и др. Рос. хим. журнал. 2015. №4. С. 85-96.

165. Домонов Д.П., Печенюк С.И., Гостева А.Н., Кривцов И.В. Вестник ЮУрГУ. Серия химия. 2014. Т. 6. №1. C. $5-16$.

166. Гостева А.Н. Диссертация на соискание ученой степени кандидата химических наук «Термическое разложение двойных комплексных соединений некоторых металлов первого переходного ряда». Санкт-Петербург. 2017.

167. Pechenyuk S.I., Zolotarev A.A., Gosteva A.N., Domonov D.P., Shimkin A.A. J. Mol. Struct. 2017. V. 1147. P. 388396.

168. Pechenyuk S., Zolotarev A., Semushina J., Gosteva A. Z. Kristallogr. 2018. V. 233. P. 35-40.

169. Wilke-Dorfurt E., Niederer K. Z. Anorg. u. allg. Chem. Bd. 1929. V. 184. P. 145.

170. Матюха В.А., Жиганов А.Н. Оксалаты переходных металлов, М.: ИздАТ. 2012. 592 с.

171. Bok L.D.C., Leipoldt J.G., Basson S.S. Z. Anorg. Allg. Chem. 1972. V. 389. P. 307.

172. Kou Hui-Zhong, Liao Dai-Zheng, Cheng Peng, Jiang Zong-Hui, Wang Geng-Lin Transition Met. Chem. 1996. V. 21. P. 349.

173. Triki S., Sala-Pala J., Thetiot F., Gomez-Garcia C.J., Daran J.-C. Eur. J. Inorg. Chem. 2006. P. 185.

174. Thetiot F., Triki S., Sala-Pala J., Gómez-García C.J. Synthetic Metals. 2005. V. 153. P. 477-480.

175. Zhan Shu-zhong, Yu Kai-bei, Liu Jiang Inorg. Chem. Commun. 2006. V. 9. P. 1007-1010. 